\title{
31. UPPER CRETACEOUS, K/T BOUNDARY, AND PALEOCENE AGGLUTINATED FORAMINIFERS FROM HOLE 959D (CÔTE D'IVOIRE-GHANA TRANSFORM MARGIN) ${ }^{1}$
}

\author{
Wolfgang Kuhnt, ${ }^{2}$ Michel Moullade, ${ }^{3}$ and Michael A. Kaminski ${ }^{4}$
}

\begin{abstract}
Upper Cretaceous agglutinated foraminifer assemblages from Hole 959D of Ocean Drilling Program (ODP) Leg 159, Côte d'Ivoire-Ghana Transform Margin, reflect the subsidence history and paleoceanography of the widening equatorial Atlantic gateway. Five benthic foraminifer assemblage types are recognized: (1) Santonian and the lowermost Campanian assemblages (Cores 159-959D-65R and 64R) are characterized by the occurrence of bathyal calcareous benthic foraminifers with an increasing proportion of agglutinated foraminifers. The disappearance of calcareous foraminifers and assemblages exclusively composed of organically cemented agglutinated forms in Section 159-959D-65R-3 reflects the subsidence of the seafloor below the calcite compensation depth (CCD); (2) lower Campanian "biofacies B" assemblages (Cores 159-959D-63R through 61R) are exclusively composed of low-diversity agglutinated foraminifers, accompanied by abundant and occasionally well-preserved radiolarian assemblages; (3) middle Campanian to upper Maastrichtian deposits (Cores 159-959D-59R through 49R) contain an exclusively agglutinated Rzehakina epigona biofacies, which is well-known from middle to deep bathyal sites along the North Atlantic margins; (4) a change in agglutinated foraminifer assemblage composition toward morphologies commonly observed in present infaunal habitats and the common occurrence of the presumably infaunal genus Spiroplectammina are observed in Core 159-959D-48R. This change in agglutinated foraminifer assemblages corresponds to the Tethyan early Paleocene "Spiroplectammina event;" (5) a diversified Paleocene "Lizard Springs type" assemblage is characterized by several diverse Rzehakina, Saccamina, and Haplophragmoides species. Assemblages from Cores 159-959D-48R through 44R display high species diversity and reflect the deepest (lower bathyal to upper abyssal) paleobathymetry.

Ranges of agglutinated foraminifer marker species and occurrences of paleoceanographic events within this biostratigraphic framework are almost identical to those observed in the North Atlantic, in the Western Tethys, and along the conjugate Brazilian margin. These observations lead us to confirm that a deep-water circulation system common to the North and South Atlantic has been active at least since the Santonian.
\end{abstract}

\section{INTRODUCTION}

Since the milestone paper of Geroch and Nowak (1984), deepwater agglutinated foraminifers (DWAF) have been used as biostratigraphic tools for Upper Cretaceous sub-calcite compensation depth (CCD) sediments in various oceanic basins. Initial DWAF zonations for the Atlantic Ocean were developed by Moullade et al. (1988) for the Cretaceous and by Kaminski (1988) for the Paleogene. More recent biostratigraphic work on DWAF includes material from the Cretaceous to Paleogene of various localities within the North Atlantic (Kuhnt et al., 1992; Kuhnt and Collins, 1996), the Western Tethys (Kuhnt and Kaminski, 1989; Bubik, 1995; Kaminski et al., 1996), the marginal basins of the South Atlantic (Volat et al., 1996), and the Western Pacific Ocean (Wightman and Kuhnt, 1992). A rough attempt to calibrate Upper Cretaceous DWAF zonations to magnetostratigraphy has been made using material from the Tethyan Cretaceous standard magnetic polarity section at Gubbio (Kuhnt, 1990).

During ODP Leg 159, the initial shipboard studies revealed that a continuous record of abundant and diverse DWAF ranging from the lowermost Campanian to the lower Eocene is present in Hole 959D (Fig.1). The purpose of our study is to conduct an initial survey of the taxonomy and biostratigraphy of DWAF in Hole 959D and also to

'Mascle, J., Lohmann, G.P., and Moullade, M. (Eds.), 1998. Proc. ODP, Sci. Results, 159: College Station, TX (Ocean Drilling Program).

${ }^{2}$ Geologisch-Paläontologisches Institut der Christian-Albrechts-Universität zu Kiel, Olshausenstr. 40, D-24118 Kiel, Federal Republic of Germany.wk@gpi.uni-kiel.de

${ }^{3}$ Laboratoire de Micropaléontologie et Géologie Marines, CNRS UMR 6526 \&GDR 88, Université de Nice-Sophia Antipolis, Parc Valrose, 06108 Nice Cedex 2, France.

${ }^{4}$ Research School of Geological and Geophysical Sciences, Birkbeck College and University College London, Gower Street, London WC1E 6BT, United Kingdom. provide new information on their paleobiogeographic significance. Thus, this study represents an additional opportunity to test the supraregional validity of existing DWAF zonations and to monitor the paleogeographic extent of paleoceanographic events that characteristically influence assemblage composition and evolution of DWAF.

\section{MATERIAL AND METHODS}

Samples of varying sizes (see Table 1) were processed for the study of benthic foraminifers. The samples were dried, weighed, soaked in distilled water, and wet-sieved through a $63-\mu \mathrm{m}$ screen; the residue was then dried. Very consolidated samples were first treated with a buffered 5\% hydrogen peroxide solution to help break them up before sieving. In rare cases, where this hydrogen peroxide treatment did not lead to complete disintegration of the clay, we soaked the dried sample in a concentrated anionic tenside solution (REWOQUAT, of REWO Chemie, Steinau an der Straße, Federal Republic of Germany), which usually disintegrated even slightly silicified samples. Generally, the complete residue was picked for benthic foraminifers. In a few exceptional samples with very high faunal content we picked only splits of the samples. Splitting was done with a standard Otto-splitter. All recorded individuals were mounted into cardboard slides for reference. The abundance data are reported (Table 1) only in numbers of identified agglutinated individuals per sample. These data are somewhat biased because fragments and unidentifiable specimens were not taken into account. The abundance of such specimens differs significantly among samples because of large differences in preservation or differential dilution by terrigenous supply. In some cases, the numbers of unidentifiable forms exceed the recorded numbers of identified individuals. For selected species (mainly forms with high preservation potential) that occur with suf- 
Figure 1. Sketch map showing the location of Hole 959D.

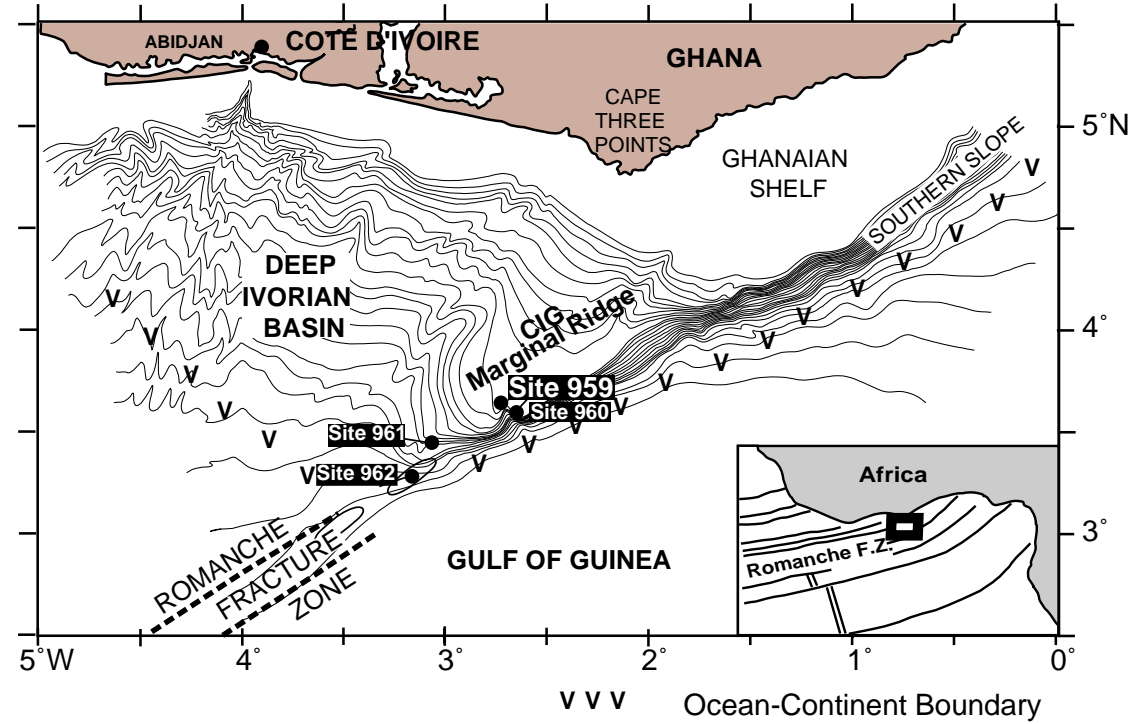

5. The first occurrences of typical Rzehakina epigona (Section 159-959D-60R-5) and Hormosina velascoensis (Section 159959D-60R-2) indicate also the lowermost Campanian. The first occurrences of these species are correlative with the base of the lowermost Campanian $C$. gigantea- $U$. jankoi overlap zone in the North Atlantic and western Tethys (Kuhnt et al., 1992).

6. In Sample 159-959D-48R-6, 28-31 cm, the last occurrence of Caudammina gigantea is observed. This species is the zonal marker of the middle Campanian-Maastrichtian Caudammina gigantea zone, which is generally recognized in deep-water sequences of the North Atlantic and Western Tethys (Geroch and Nowak, 1984; Moullade et al., 1988). In Hole 959D, Caudammina gigantea first occurs in Sample 159-959D-49R6, 27-30 cm (upper Maastrichtian). This late first occurrence of $C$. gigantea is unusually high and is probably controlled by the subsidence history of the site. $C$. gigantea, a typical abyssal species, has an upper depth limit of its distribution estimated as corresponding to lower bathyal depths (Kuhnt and Kaminski, 1990). The water depth at Site 959 was probably too shallow for $C$. gigantea before the late Maastrichtian.

7. The DWAF assemblage in Core 159-959D-48R is characterized by a distinct acme of Spiroplectammina spectabilis, a cosmopolitan Paleogene form (Kaminski, 1988). A single occurrence of Conotrochammina whangaia, a Paleocene marker in the North Atlantic and its marginal basins (Kuhnt and Kaminski, 1990), is observed in Sample 159-959D-48R$5,28-31 \mathrm{~cm}$.

8. A late Paleocene (Selandian/Thanetian) age assignment is based on the first occurrence (FO) of Reticulophragmoides jarvisi in Sample 159-959D-44R, CC. The FO of this species has been observed in the lower part of the upper Paleocene at several localities in the Atlantic and North Sea (Gradstein and Kaminski, 1989). The earliest forms of this species (from Zone P3 in Zumaya and Tunisia) are flat and resemble its assumed ancestor, Haplophragmoides walteri. Younger specimens, such as the types in the Cushman Collection (from Zone P5 in Trinidad), have a more lenticular shape. Such typical late Paleocene specimens were found in Sample 159-959D-43R-1, $28-32 \mathrm{~cm}$. Other species that characterize the upper Paleocene at Lizard Springs include the large Paleogene form of Haplophragmoides walteri (FO in Sample 159-959D-47R-1, 19-22 
Table 1. Distribution of agglutinated foraminifers in the Upper Cretaceous and lowermost Paleogene of Hole 959D.

\begin{tabular}{|c|c|c|c|c|c|c|c|c|c|c|c|c|c|c|c|c|c|c|c|c|c|c|c|c|c|c|c|c|c|c|}
\hline $\begin{array}{l}\text { Core, section, } \\
\text { interval }(\mathrm{cm})\end{array}$ & 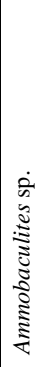 & 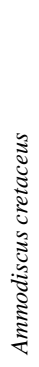 & 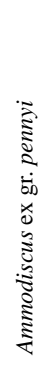 & 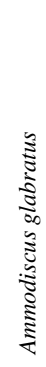 & 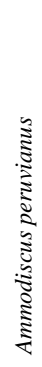 & 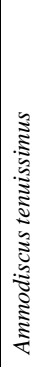 & 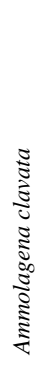 & 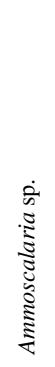 & 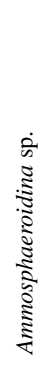 & 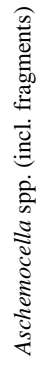 & 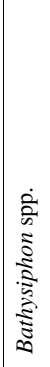 & 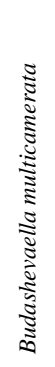 & 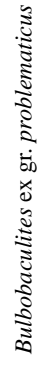 & 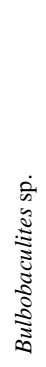 & 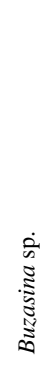 & 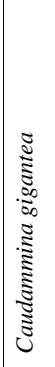 & 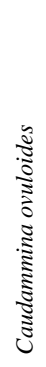 & 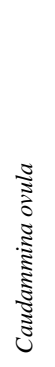 & 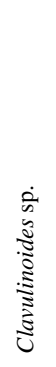 & 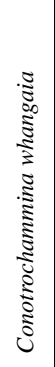 & 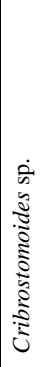 & 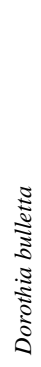 & 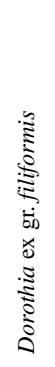 & $\begin{array}{l}\dot{2} \\
\dot{3} \\
\dot{3} \\
\vdots \\
0 \\
0\end{array}$ & 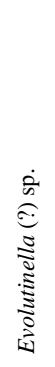 & 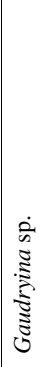 & 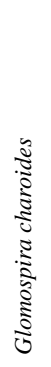 & 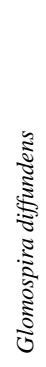 & 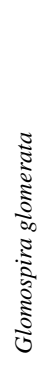 & 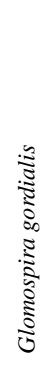 \\
\hline \multicolumn{31}{|l|}{ 159-959D- } \\
\hline $43 \mathrm{R}-3,34-36$ & . & . & . & . & 4 & 5 & . & . & 11 & 1 & $\begin{array}{r}21 \\
9\end{array}$ & . & . & . & 1 & . & . & . & 4 & 1 & . & . & . & . & . & . & 6 & 2 & . & . \\
\hline $43 \mathrm{R}-5,32-35$ & . & . & . & . & 1 & 4 & . & . & . & . & 3 & . & . & . & & . & . & . & . & . & . & . & . & 1 & . & r. & & 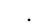 & & - \\
\hline 43R-CC & . & . & . & . & 2 & 1 & 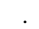 & . & 4 & 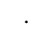 & 3 & . & . & . & 1 & . & 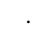 & 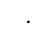 & 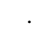 & . & 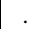 & 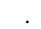 & . & 1 & . & . & 2 & . & . & . \\
\hline $44 \mathrm{R}-2,16-22$ & . & . & . & . & 6 & & . & . & 4 & 1 & 3 & . & . & . & . & . & . & . & 1 & 1 & & . & . & 1 & . & . & 5 & . & . & \\
\hline $44 \mathrm{R}-3,30-33$ & . & . & . & . & & 3 & t & . & 2 & 2 & 10 & . & . & . & . & . & . & . & . & 3 & 1 & . & . & . & . & . & 5 & & 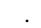 & 1 \\
\hline $44 \mathrm{R}-5,30-33$ & . & . & . & . & 2 & 3 & 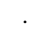 & . & 36 & 15 & & . & . & . & . & . & . & . & . & . & - & & . & . & . & . & 12 & 1 & . & 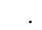 \\
\hline $44 \mathrm{R}-6,30-33$ & . & . & . & 4 & & 7 & . & . & 8 & 13 & 13 & . & . & . & . & . & . & 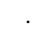 & . & 1 & . & . & . & . & . & . & 4 & 1 & . & \\
\hline 44R-CC & . & . & . & . & 1 & 2 & . & . & 2 & 10 & 16 & . & . & . & . & . & . & . & . & . & . & . & . & . & . & . & . & . & . & 1 \\
\hline $45 \mathrm{R}-1,43-48$ & . & 1 & . & . & 2 & 4 & . & . & 5 & 2 & 13 & . & . & . & & . & . & . & . & . & . & . & . & . & . & . & 2 & . & . & . \\
\hline $45 \mathrm{R}-\mathrm{CC}$ & . & . & . & . & 1 & 2 & . & . & 6 & 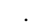 & 36 & . & 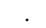 & . & 2 & . & . & . & 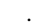 & . & 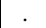 & 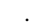 & . & . & . & . & 5 & . & $\cdot$ & . \\
\hline $46 \mathrm{R}-1,80-85$ & . & 1 & . & . & 2 & 7 & . & . & 9 & 6 & 37 & . & . & . & . & . & . & . & . & . & 3 & - & . & . & . & . & 6 & . & . & . \\
\hline 46R-CC & & & . & . & 4 & 8 & . & . & 15 & & 26 & . & . & . & . & . & . & . & 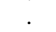 & . & . & 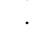 & . & . & . & 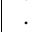 & 13 & . & & . \\
\hline $47 \mathrm{R}-1,19-22$ & 1 & 1 & . & . & 1 & 3 & . & . & 11 & 3 & 11 & . & . & . & . & . & . & . & . & . & . & . & . & . & . & $\cdot$ & 4 & . & 1 & . \\
\hline $48 \mathrm{R}-1,28-31$ & . & 2 & . & . & . & 2 & . & . & 1 & 16 & 5 & . & . & . & . & . & . & . & . & . & . & . & . & . & . & . & 4 & . & . & \\
\hline $48 \mathrm{R}-1,69-70$ & . & 3 & . & . & 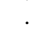 & & 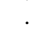 & . & . & 2 & 1 & . & . & . & . & . & . & . & . & . & . & 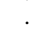 & . & . & . & 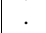 & 6 & . & . & 1 \\
\hline $48 \mathrm{R}-2,27-30$ & & 1 & . & . & . & 1 & & . & 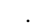 & 27 & 13 & . & . & . & . & . & . & . & 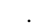 & . & & . & . & . & . & $\cdot$ & 3 & . & . & . \\
\hline $48 \mathrm{R}-3,31-34$ & 2 & . & . & . & & 5 & & . & 6 & 60 & 14 & . & . & . & & . & . & . & . & . & 3 & & . & . & . & . & 2 & . & . & . \\
\hline $48 \mathrm{R}-3,137-139$ & 3 & . & . & . & 5 & 14 & t & . & 12 & & 16 & . & . & . & 1 & . & . & . & . & . & 9 & 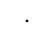 & . & . & . & . & 7 & . & . & . \\
\hline $48 \mathrm{R}-4,28-31$ & . & . & . & . & . & 4 & . & . & 9 & 12 & 14 & . & . & & . & . & . & . & . & . & . & . & . & . & . & . & 3 & . & . & . \\
\hline $48 \mathrm{R}-4,48-50$ & . & . & & . & . & 1 & & . & . & 1 & & . & . & 1 & . & . & . & . & . & . & . & 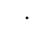 & . & . & . & 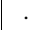 & 5 & . & . & . \\
\hline $48 \mathrm{R}-4,66-68$ & . & . & 2 & . & . & . & ${ }^{\circ}$ & . & . & . & 5 & . & . & & . & . & . & . & . & . & . & . & . & . & . & . & 7 & . & . & . \\
\hline $48 \mathrm{R}-4,69-71$ & . & . & . & . & & . & . & . & 2 & 3 & 2 & . & . & 1 & & . & . & . & . & 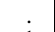 & & . & . & . & . & . & 1 & . & . & . \\
\hline $48 \mathrm{R}-5,28-31$ & . & 1 & . & . & 1 & . & . & . & 5 & 5 & 9 & . & . & . & 1 & . & . & . & . & 1 & 1 & ${ }^{\circ}$ & . & . & . & . & 1 & . & . & . \\
\hline $48 \mathrm{R}-5,87-89$ & . & 1 & . & . & & & & . & 1 & 8 & 1 & . & . & . & . & & 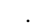 & & . & . & & & . & . & . & 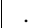 & 3 & . & . & . \\
\hline $48 \mathrm{R}-6,28-31$ & . & . & . & & 2 & 10 & & . & 23 & 50 & 40 & . & . & . & . & 7 & & 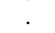 & 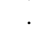 & & 7 & 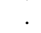 & . & . & . & . & 9 & . & . & . \\
\hline 48R-CC & & & . & 1 & $\cdot$ & 16 & 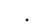 & . & 5 & 9 & 26 & . & . & . & . & & 1 & & 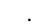 & 1 & & . & . & . & . & . & 12 & . & $\cdot$ & . \\
\hline $49 \mathrm{R}-1,28-31$ & 6 & 8 & . & . & . & 10 & & . & 9 & 9 & 33 & . & . & . & . & 14 & & 3 & r. & . & 1 & $\cdot$ & . & . & . & . & 18 & . & . & . \\
\hline $49 \mathrm{R}-1,69-72$ & . & 1 & . & . & . & . & . & . & 1 & 6 & & . & . & . & . & 5 & 1 & & . & . & & . & . & . & . & . & 5 & . & . & . \\
\hline $49 \mathrm{R}-1,110-11$ & & 3 & . & . & . & & & . & 8 & & & 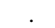 & - & & 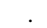 & 18 & 1 & 3 & & 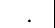 & 3 & & . & & . & & 6 & . & . & . \\
\hline $49 \mathrm{R}-2,27-30$ & $4(?)$ & 6 & . & . & 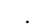 & 7 & & . & 1 & 1 & 29 & . & . & 2 & . & 1 & . & 3 & 1 & & & 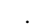 & . & 4 & . & 1 & 10 & . & . & . \\
\hline $49 \mathrm{R}-3,27-30$ & 5 & 5 & . & . & 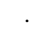 & 8 & & 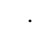 & 3 & 1 & & . & . & 1 & . & 3 & . & . & . & $1(?)$ & 4 & . & . & & . & 1 & 6 & . & . & . \\
\hline $49 \mathrm{R}-4,27-30$ & 5 & & & . & . & . & & & . & & 1 & . & 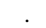 & . & . & 1 & 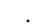 & . & & $3(?)$ & . & & . & 6 & . & 1 & & . & $\cdot$ & . \\
\hline $49 \mathrm{R}-4,69-72$ & 1 & 3 & 1 & . & & 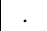 & 1 & & 2 & 44 & 2 & 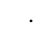 & . & . & . & 5 & & . & 43 & $2(?)$ & . & & . & 5 & & 3 & 2 & . & . & . \\
\hline $49 \mathrm{R}-5,27-31$ & & 2 & & . & . & & . & 1 & 5 & 3 & 2(?) & . & . & . & . & 1(?) & & . & 7 & $1(?)$ & . & . & . & . & 1 & . & . & . & . & . \\
\hline $49 \mathrm{R}-6,27-30$ & 1 & 7 & 3 & . & . & 8 & . & $3(?)$ & 25 & 10 & 30 & . & . & . & . & $5(?)$ & 1 & . & . & $\cdot$ & . & . & . & . & . & . & 1 & . & . & . \\
\hline $50 \mathrm{R}-1,27-30$ & . & . & 1 & . & & . & . & . & 2 & 3 & . & 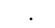 & 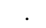 & . & . & . & & 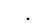 & & 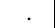 & . & & . & . & . & . & . & . & . & . \\
\hline $50 \mathrm{R}-1,70-73$ & & & & 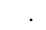 & & . & . & & & 1 & & . & . & & . & . & 1 & 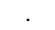 & 1 & . & . & . & . & . & . & . & & . & . & \\
\hline $50 \mathrm{R}-2,26-29$ & 1 & 1 & . & . & • & . & . & 6 & 16 & 4 & 8 & 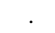 & . & 1 & . & . & . & . & . & & . & . & . & . & . & . & 2 & . & . & 2 \\
\hline 50R-3, 28-31 & 1 & 3 & . & . & . & . & $\cdot$ & 3 & . & 3 & 3 & . & 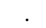 & . & . & . & . & . & . & $4(?)$ & . & & . & . & . & . & 1 & . & $v^{\circ}$ & . \\
\hline $50 \mathrm{R}-4,26-29$ & 2 & 1 & . & . & & . & 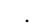 & 1 & 2 & 5 & . & 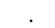 & . & . & . & . & & . & . & 1 & & & . & & . & . & . & . & . & . \\
\hline $50 \mathrm{R}-4,68-71$ & & 1 & 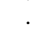 & . & " & . & 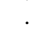 & 10 & 10 & 11 & & 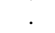 & . & . & . & 1 & 2 & & . & 2 & 1 & & " & 3 & . & . & & . & . & 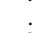 \\
\hline 50R-5, 30-34 & 1 & 1 & & . & & . & & 2 & 10 & 4 & 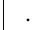 & 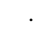 & . & . & . & . & & & . & . & $\cdot$ & 2 & e & . & . & . & 2 & . & & 2 \\
\hline $51 \mathrm{R}-3,28-31$ & . & 5 & 1 & . & & . & & 1 & 2 & 2 & 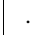 & 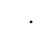 & . & . & . & . & 5 & $1(?)$ & . & . & . & 1 & . & & . & . & & $\cdot$ & 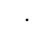 & . \\
\hline $52 \mathrm{R}-1,23-27$ & . & 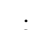 & 4 & . & & . & & . & & 2 & & 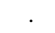 & . & . & . & . & . & . & . & . & . & . & . & 1 & . & . & 1 & . & . & . \\
\hline $52 \mathrm{R}-1,29-33$ & . & 2 & . & . & 1 & . & & . & 1 & 12 & & 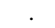 & . & . & . & . & . & . & . & . & . & . & . & . & . & . & &. &. & . \\
\hline $52 \mathrm{R}-1,67-71$ & . & . & . & . & . & . & & . & 1 & 11 & 1 & & ${ }^{\circ}$ & . & . & . & . & . & . & . & . & . & . & . & . & . & 2 & . & $\cdot$ & . \\
\hline $52 \mathrm{R}-2,25-27$ & . & . & . & . & . & . & & . & 1 & 4 & . & & . & . & . & . & . & . & . & . & . & . & & . & . & . & . & . & . & . \\
\hline $52 \mathrm{R}-3,27-31$ & . & . & . & . & . & . & . & . & 1 & 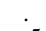 & & $1(?)$ & . & . & . & . & . & . & . & . & . & . & $2(?)$ & . & . & . & . & . & . & . \\
\hline $52 \mathrm{R}-4,30-33$ & . & . & . & . & . & . & . & . & 1 & 5 & 4 & & . & . & . & . & . & . & . & 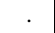 & . & 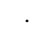 & & & . & . & . & . & . & . \\
\hline $52 \mathrm{R}-4,45-48$ & $\cdot$ & . & . & . & . & . & . & 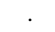 & . & 1 & & $1(?)$ & . & . & . & . & . & 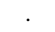 & 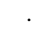 & & . & . & $2(?)$ & $\cdot$ & . & . & . & $\cdot$ & $\cdot$ & . \\
\hline
\end{tabular}

$\mathrm{cm}$ ), Glomospira diffundens (FO in Sample 159-959D-44R-6, 30-33 cm), Trochammina ruthvenmurrayi (in Sample 159959D-43R, CC), the late Paleocene morphotype of Conotrochammina whangaia with more open coiling and a deep umbilicus, and Spiroplectammina excolata (in Sample 159-959D43R-1, 28-32 cm). The presence of Rzehakina fissistomata (the index taxon of the Paleocene R. fissistomata zone of Geroch and Nowak, 1984) in Hole 959D suggests faunal similarities with the upper Paleocene of the western Tethys. However, equally important in this respect is the notable absence of Glomospira grzybowskii, a form that is common in the Paleocene throughout the Carpathian region. Only a single occurrence of this species was observed in Hole 959D. The recurrence of calcareous benthic foraminifers (a diverse "Velasco-type" assemblage dominated by Gavelinella becariiformis and Nuttallides truempyi) was observed in Sample 159959D-44R-3, 30-33 cm, signalling a drop in the CCD.

\section{Paleobathymetry}

Within Core 159-959D-65R a major change is observed from calcareous deep-water benthic foraminifer assemblages (Samples 159959D-65R-7, 31-35 cm, to 159-959D-65R-4, 30-34 cm) to assemblages exclusively composed of agglutinated forms with organic cement. This change in assemblage composition can only be explained by a subsidence of the depositional environment below the 
Table 1 (continued).

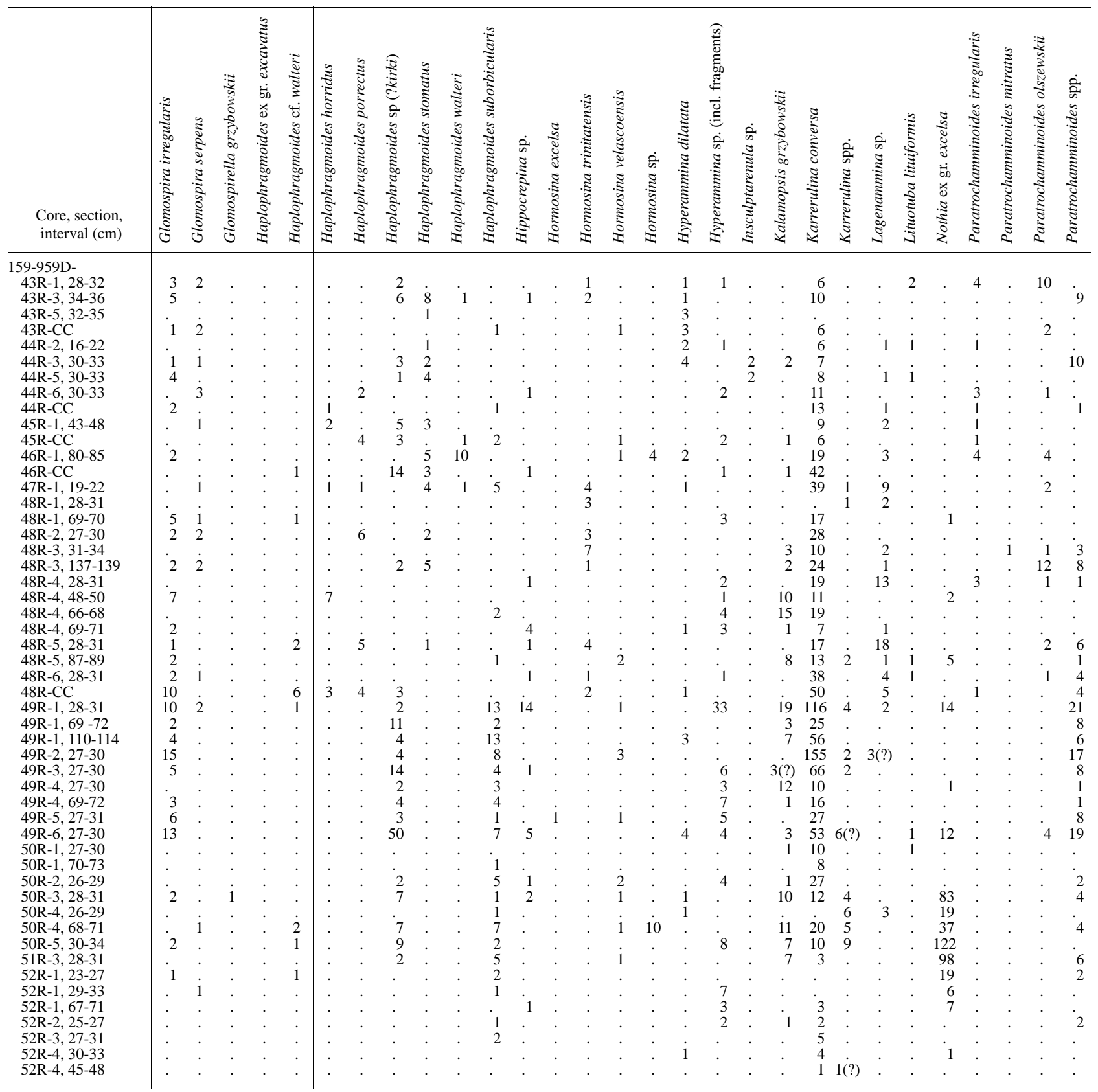

CCD during the early Campanian. The position of the CentralAtlantic CCD was high at this time (at $\sim 3000 \mathrm{~m}$, Kuhnt and Moullade, 1991), and it may have been even shallower along the West African margins and the equatorial Atlantic gateway, affected by an oxygen deficiency (oxygen minimum zone) in its mid-water masses (see discussion in Holbourn and Kuhnt, Chap. 30, this volume). An increasing water depth since the early Campanian may be deduced from the increasing diversity of agglutinated assemblages (Fig. 3) and from a successive increase upsection in abundance of typical deep bathyal-abyssal species such as Pseudobolivina spp., Karrerulina conversa, and Rhabdammina cylindrica. The late first occurrence of the typical abyssal species Caudammina gigantea (see Kuhnt and Kaminski, 1990) at the base of Core 159-959D-49R is also probably indicative of a water depth of at least 2500 to $3000 \mathrm{~m}$ in the late Maastrichtian.

The Paleocene assemblages are diverse, and display strong similarities to the classic "Lizard Springs Fauna" described by Cushman and Renz (1946) and Kaminski et al. (1988). This type of assemblage with abundant tubular forms and Rzehakina is interpreted as indicating lower bathyal to upper abyssal depths, probably in a lower slope or continental-rise setting (Kaminski et al., 1988). The presence of an array of cosmopolitan deep-water species in this assemblage at Site 959 suggests a deeper environmental setting than in the CampanianMaastrichtian.

Our present observations in the Gulf of Guinea are consistent with those made along the conjugate South American margin in the Sergipe Basin (Brazil) by Koutsoukos and Hart (1990), Koutsoukos 
Table 1 (continued).

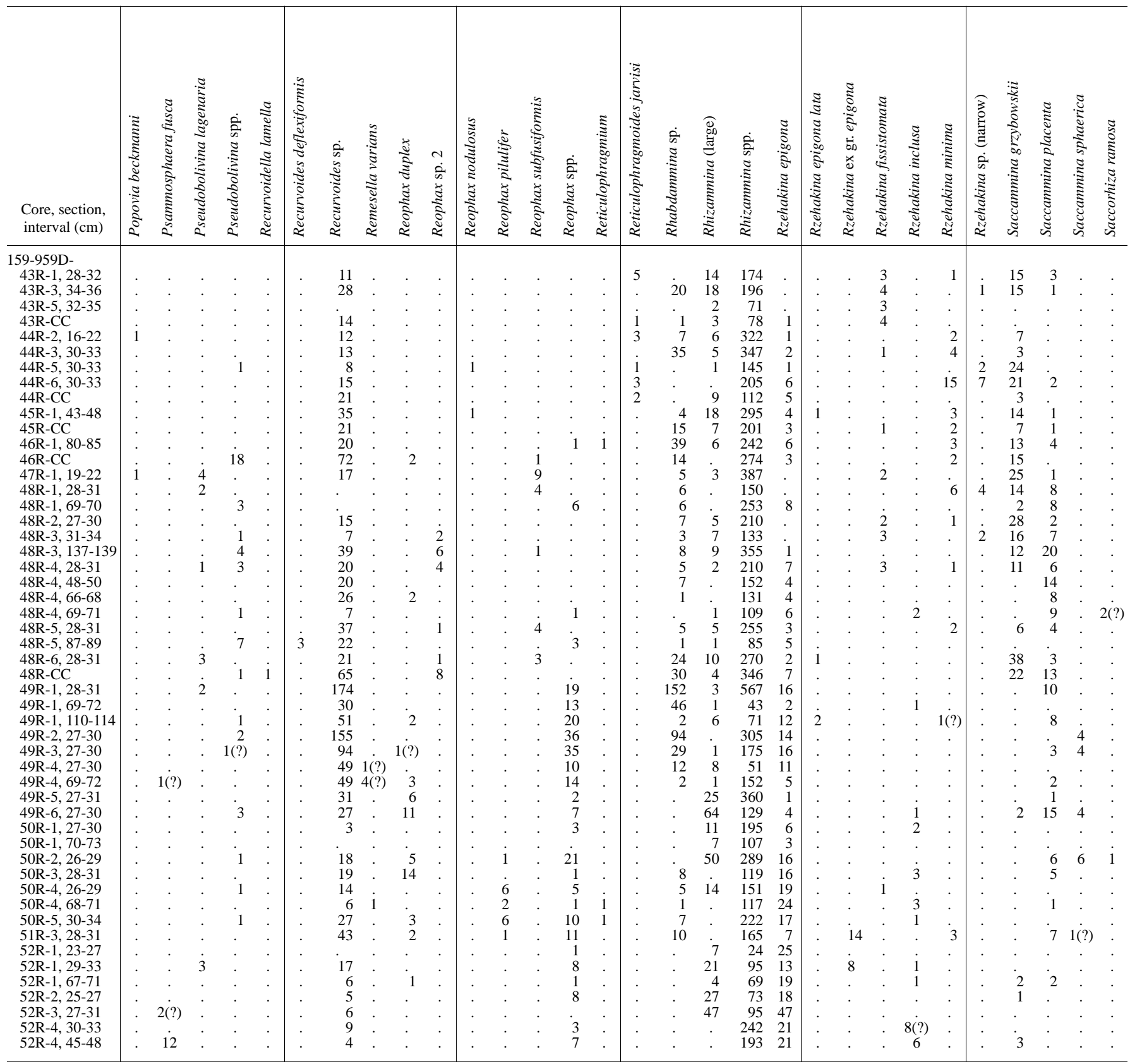

(1992), Koutsoukos and Bengtson (1993), and Koutsoukos et al. (1993). Along the northeastern and equatorial Brazilian margin, these authors have recognized an important deepening event that occurred by late Coniacian-early Santonian times, and was brought about by the final structural detachment of the South American and African plates. According to these authors, this late Coniacian-early Santonian event resulted in the establishment of a deep-oceanic circulation regime, which is reflected in a remarkable change in the sedimentary sequence from a carbonate-dominated (Cenomanian-middle Coniacian) to a siliciclastic cycle (Koutsoukos et al., 1993). Koutsoukos (1992) observed a sharp increase in species diversity of the benthic foraminifers in the upper Coniacian-Maastrichtian, with a maximum in the lower Campanian. The total diversity of benthic foraminifers progressively declined after the early Campanian maximum in a step- wise pattern. In the Sergipe Basin, middle-lower bathyal late Coniacian-Santonian to Maastrichtian foraminifer assemblages are enriched in agglutinated specimens (Koutsoukos and Hart, 1990) the composition of which presents certain similarities with the Leg 159 material.

\section{Paleoceanographic Events}

\section{Lower Campanian Event (LCE)}

A very prominent interval of biosiliceous sedimentation is observed within Cores 159-959D-61R to 63R. Microfossil assemblages within this interval are characterized by poorly preserved agglutinated foraminifers, mainly composed of unidentifiable, flattened and silicified tests and abundant but poorly preserved radiolarians. The 
Table 1 (continued).

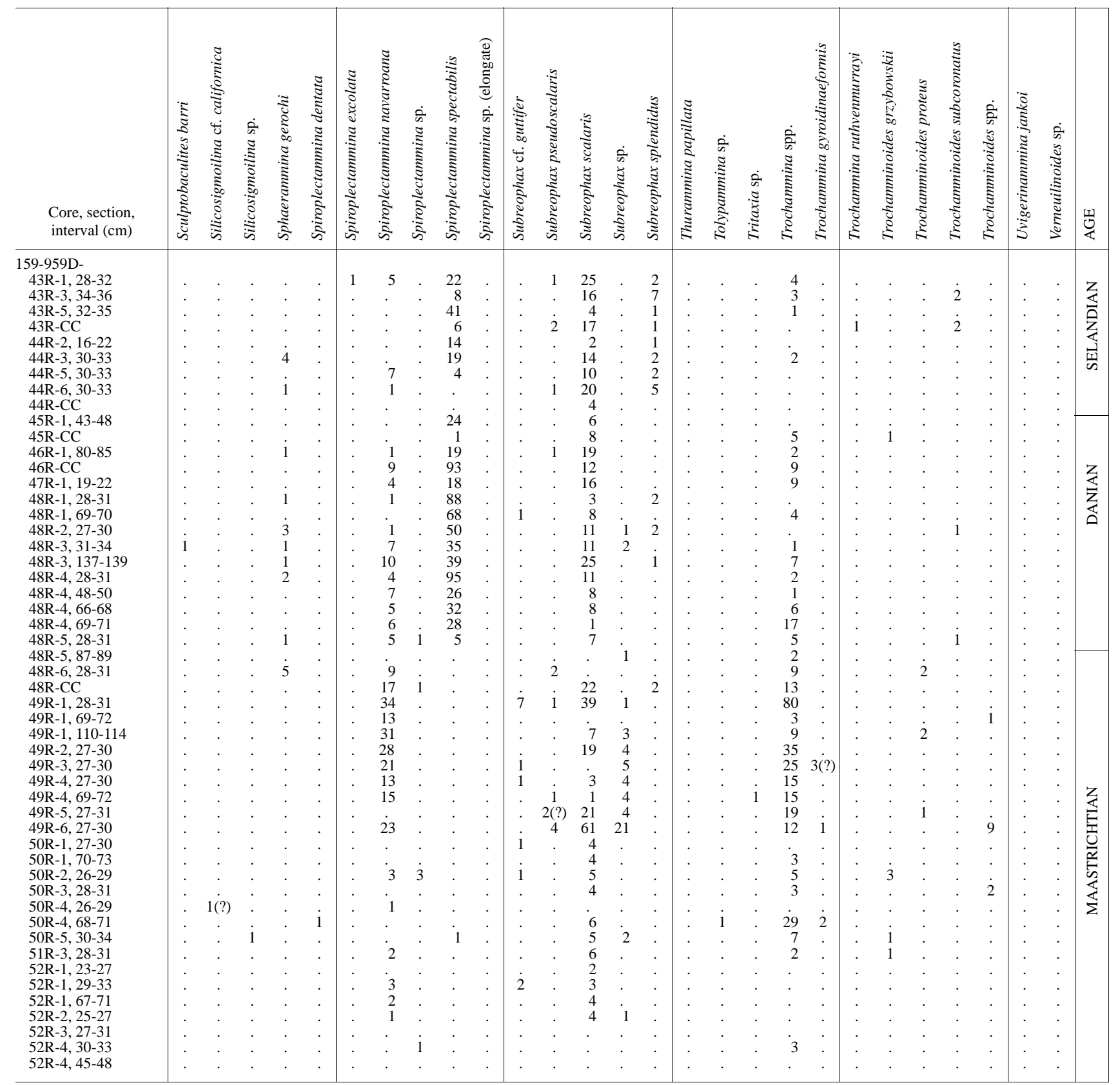

last occurrence of Uvigerinammina jankoi is at the top of this interval, dating this biosiliceous event between the lowermost Campanian and the base of the middle Campanian.

A similar lower Campanian radiolarian-rich interval with comparable changes in assemblage composition of benthic foraminifers has been observed in Deep Sea Drilling Project (DSDP) Holes 368, 385, 386, 398D, 543, 543A, 603B, ODP Hole 641A, and outcrop sections in northern Morocco, southern Spain, Zumaya (northern Spain), Gubbio (Italy), Bad Reichenhall (the Bavarian Alps), and the Romanian Eastern Carpathians (Herm, 1962; Neagu, 1968; Butt, 1981; Hemleben and Troester, 1984; Kuhnt et al., 1989; Kuhnt, 1992). Characteristic features in this interval include (1) increased importance of pelagic carbonate ooze and biosiliceous, radiolarian-rich sedimentation; (2) geochemical and micropaleontological evidence for deep-water oxygen deficiency; (3) low diversity assemblages of opportunistic deep-water benthic foraminifers, followed by an important radiation; and (4) extinction of several major groups of planktonic foraminifers. Available geochemical and stable isotope data are indicative of changes in the composition of surface and deep-water masses during a short time interval in the early Campanian (Globotruncanita elevata planktonic foraminifer zone, Goesella rugosa/ Caudammina gigantea benthic foraminifer zone, reversed part of Chron 34 of the paleomagnetic time scale). During this period, a short-term warming that may have occurred and flooded the Tethyan shelf areas during the corresponding transgressive cycle may also have been a source for increased formation of warm saline bottom waters, resulting in changes of the western Tethyan and Central Atlantic deep-water circulation. The micropaleontological record of Hole 959D provides first indications of the occurrence of this early Campanian paleoceanographic event in the South Atlantic. This led 
Table 1 (continued).

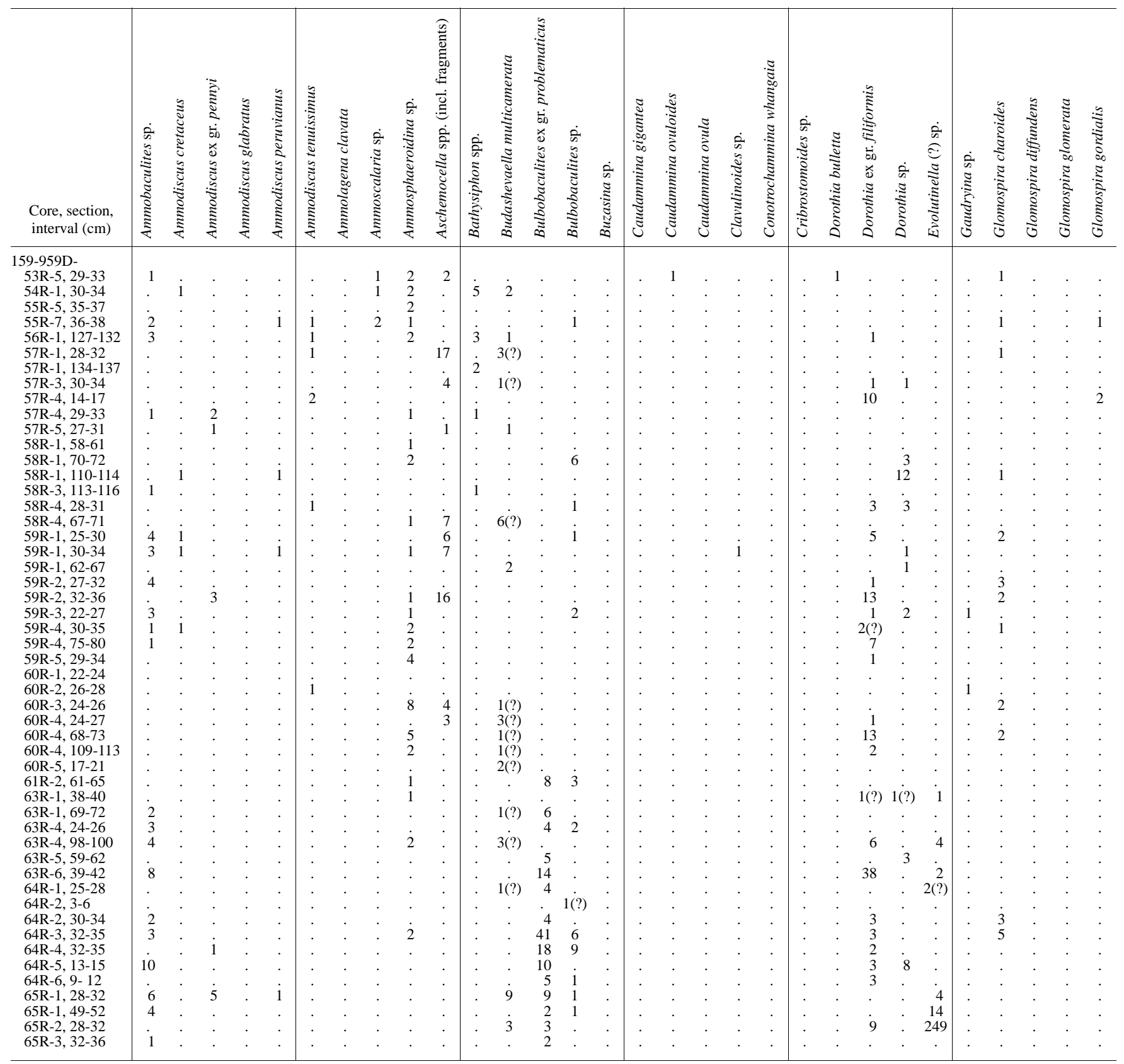

us to suggest that a deep-water circulation system was already wellestablished between the North and South Atlantic at this time.

\section{K/T Boundary Event}

Quantitative changes in benthic foraminifer composition were observed across the K/T boundary within Cores 159-959D-48R and 159-959D-49R (Fig. 4). The main changes are (1) a decrease in abundance and finally the LO of Caudammina gigantea in Sample 159959D-48R-6, 28-31 cm; (2) a general decrease in epifaunal detritus feeders (e.g., rzehakinids and some ammodiscids), which indicates moderate to high organic carbon fluxes (as a typical representative of this group, the abundance values of Rzehakina epigona are plotted in Fig. 4); and (3) a drastic increase in abundance of the genus Spiroplectammina within Section 159-959D-48R-4, corresponding to the earliest Paleocene Spiroplectammina event (Kuhnt and Kaminski, 1996).

Changes in Hole 959D Cores 159-959D-48R through 49R are comparable to the observations made in deep-water sections in northern Spain (Zumaya and Sopelana sections, Kuhnt and Kaminski, 1993), southern Spain (Caravaca section, Coccioni and Galeotti, 1994), and central Italy (Contessa, Bottaccione, and Petriccio sections, Kuhnt, 1990; Kuhnt and Kaminski, 1996). In these areas, the following characteristic succession of agglutinated foraminifer assemblages is observed within the K/T boundary interval: (1) late Maastrichtian deep-water agglutinated foraminifer (DWAF) assemblages are dominated by epifaunal suspension- and detritus-feeders (e.g., astrorhizids and some ammodiscids); (2) foraminifer assemblages within and directly above the boundary clay are dominated by infaunal agglutinated species (Reophax, Subreophax, Ammobaculites 
Table 1 (continued).

\begin{tabular}{|c|c|c|c|c|c|c|c|c|c|c|c|c|c|c|c|c|c|c|c|c|c|c|c|c|c|c|c|c|c|}
\hline $\begin{array}{l}\text { Core, section, } \\
\text { interval }(\mathrm{cm})\end{array}$ & 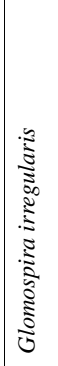 & 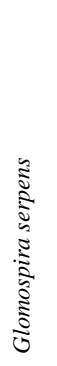 & 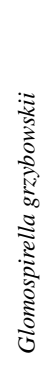 & 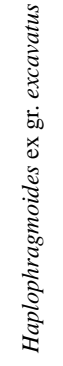 & 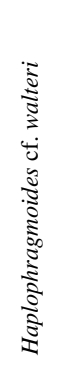 & 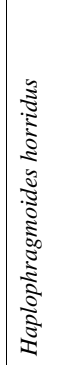 & 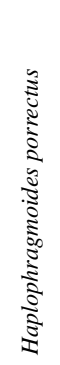 & 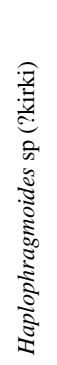 & 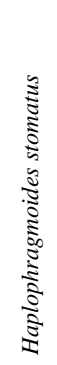 & 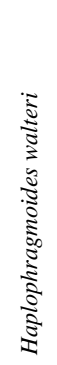 & 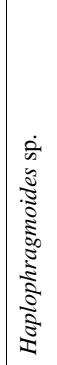 & 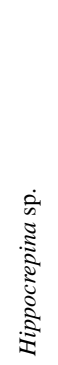 & 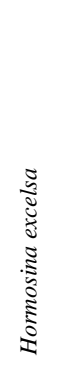 & 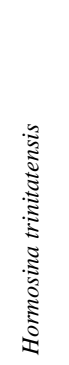 & 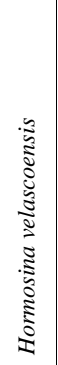 & 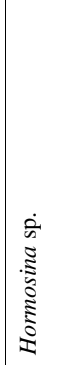 & 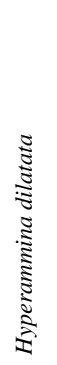 & 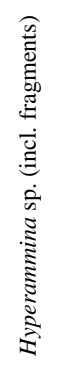 & 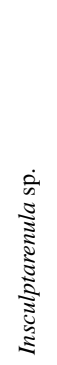 & 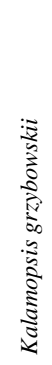 & 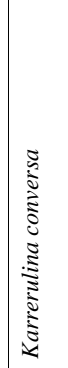 & 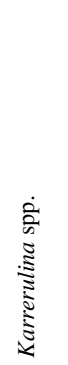 & 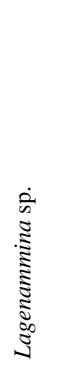 & 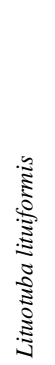 & 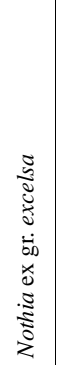 & 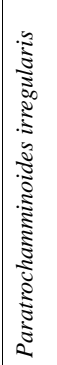 & 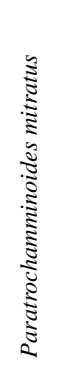 & 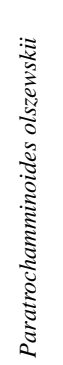 & 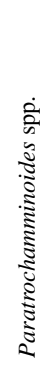 \\
\hline 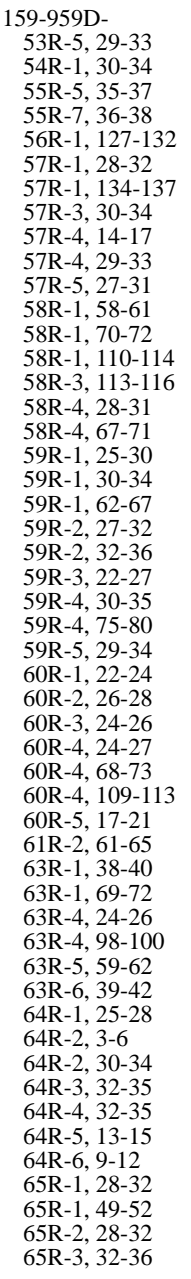 & 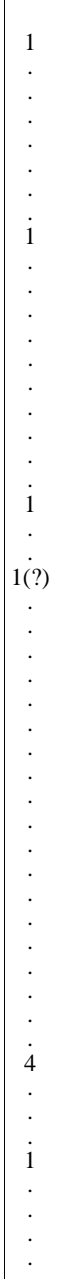 & $\begin{array}{l}1 \\
. \\
. \\
. \\
. \\
.\end{array}$ & $\begin{array}{l}\vdots \\
\vdots \\
\vdots \\
\vdots \\
\vdots \\
\vdots \\
\vdots \\
\vdots \\
\vdots \\
\vdots\end{array}$ & 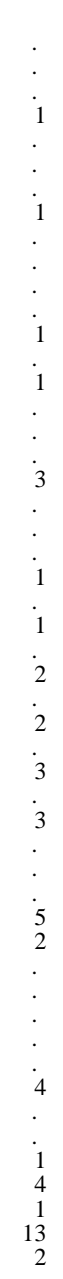 & 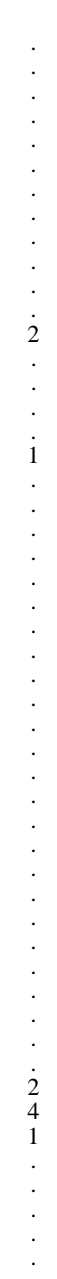 & $\begin{array}{l}\text { i } \\
\vdots \\
\vdots \\
\vdots\end{array}$ & i & 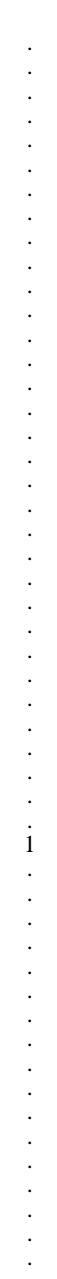 & : & $\begin{array}{l}\dot{y} \\
\vdots\end{array}$ & 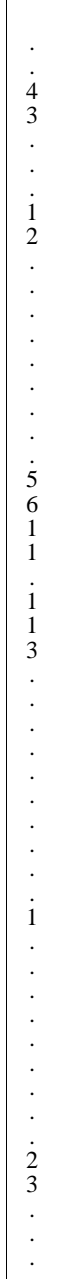 & $\begin{array}{l}: \\
: \\
: \\
: \\
: \\
: \\
: \\
: \\
: \\
: \\
: \\
: \\
: \\
: \\
: \\
: \\
: \\
: \\
: \\
:\end{array}$ & $\begin{array}{l}: \\
: \\
:\end{array}$ & . & $\begin{array}{l}4 \\
\vdots \\
\vdots \\
\vdots \\
\vdots \\
\vdots \\
\vdots \\
\vdots \\
\vdots \\
\vdots\end{array}$ & : & 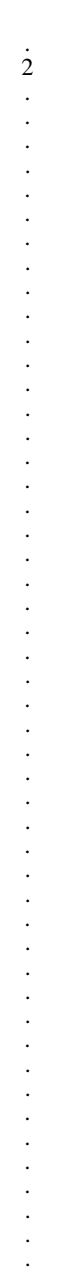 & $\begin{array}{c}2 \\
3 \\
5 \\
1 \\
17 \\
7 \\
3 \\
\cdot \\
3 \\
\cdot \\
: \\
7 \\
7 \\
1 \\
: \\
: \\
: \\
:\end{array}$ & : & 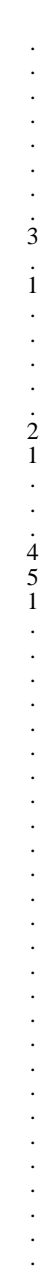 & \begin{tabular}{|c}
6 \\
2 \\
2 \\
27 \\
6 \\
. \\
\\
1 \\
2 \\
3 \\
12 \\
$\cdot$ \\
3 \\
10 \\
1 \\
4 \\
3 \\
30 \\
. \\
$6(?)$ \\
2 \\
2 \\
6 \\
2 \\
18 \\
20 \\
4 \\
14 \\
9 \\
1 \\
16 \\
7 \\
3 \\
3 \\
12 \\
$\dot{1}$ \\
14
\end{tabular} & 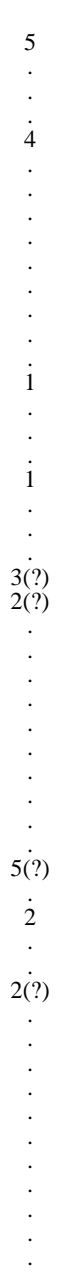 & 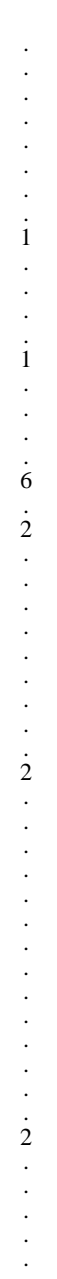 & $\begin{array}{l}1 \\
1 \\
\vdots \\
\vdots \\
\vdots \\
\vdots\end{array}$ & 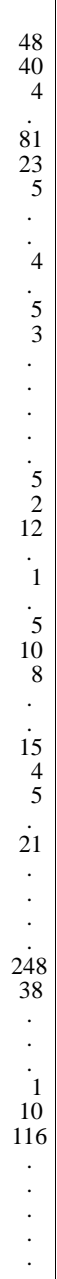 & & $\begin{array}{l}\dot{0} \\
\vdots \\
\end{array}$ & 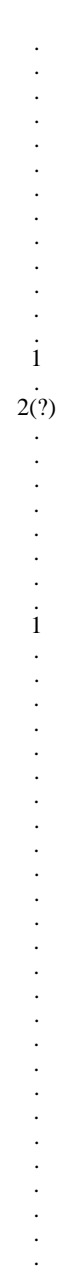 & $\begin{array}{l}i \\
i \\
i \\
i \\
.\end{array}$ \\
\hline
\end{tabular}

and Recurvoides); and (3) a strong increase of infaunal calcareous agglutinating Spiroplectammina and Dorothia is observed in deepwater environments when the organic flux recovers.

These quantitative faunal changes in deep-water agglutinated foraminifers across the K/T boundary are consistent with a model of decreased surface productivity, and a collapse of the food web for deepwater benthic communities at the K/T boundary. Benthic foraminifer populations slowly recover to background levels over a time span of at least $300 \mathrm{k} . \mathrm{y}$. following the K/T boundary event. Most Maastrichtian species of deep-water benthic foraminifers recur after this recovery phase and, as a result, the overall faunal turnover of benthic foraminifers across the K/T boundary does not remarkably exceed normal turnover rates in the Late Cretaceous or early Paleogene (Kuhnt et al., 1996). Spiroplectammina-dominated bathyal benthic foraminifer assemblages characterize the recovery phase of the marine eco- system and are potentially useful correlation tools for the interval from the top of the P0 Zone to the lower part of the P. eugubina zone.

\section{CONCLUSIONS}

The deep-water agglutinated foraminifer zonations of Geroch and Nowak (1984) for the Polish Carpathians, Moullade et al. (1988) for the North Atlantic, and Kuhnt et al. $(1989,1992)$ for the western Tethys can be applied to the Campanian-Paleogene interval of Hole 959D. Three zones are identified: (1) the Uvigerinammina jankoil Caudammina ovulum gigantea concurrent zone (lower Campanian), (2) the Caudammina ovulum gigantea zone (middle Campanian to upper Maastrichtian), (3) the Rzehakina epigona/Spiroplec-tammina spectabilis zone (lower Paleocene). 
Table 1 (continued).

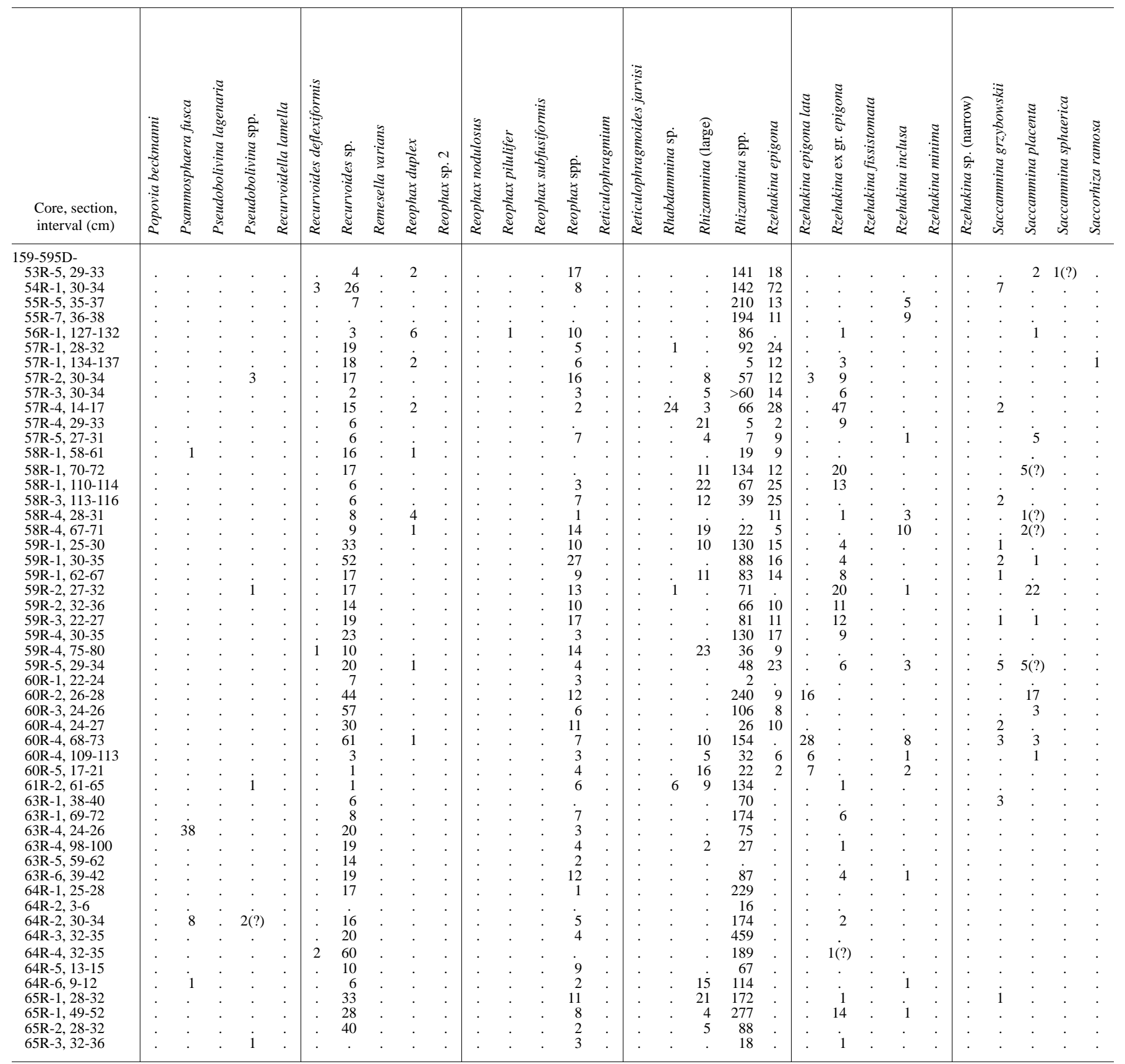

The disappearance of calcareous foraminifers and the occurrence of assemblages exclusively composed of organically cemented agglutinated forms in Section 159-959D-65R-3 are attributed to the subsidence of the seafloor below the CCD.

The North Atlantic early Campanian paleoceanographic event is reflected in a biosiliceous radiolarian facies and associated changes in the benthic biofacies within Core 159-959D-61R.

The drastic decrease in surface productivity and a collapse of the food web for deep-water benthic communities across the K/T boundary probably led to the extinction of large-sized hormosinids (i.e., Caudammina gigantea). A significant increase in individuals of the genus Spiroplectammina and the first common occurrence of the Paleogene species Spiroplectammina spectabilis are observed within Core 159-959D-48R. This "Spiroplectammina event" characterizes the recovery phase of the marine ecosystem after the K/T boundary in several classic boundary sections and is used as an indicator of the interval from the top of the P0 to the lower part of the G. eugubina zones in several classic boundary sections. Although precise calibrations to the planktonic foraminifer zonation are lacking, the thickness of the $S$. spectabilis acme in Hole 959D suggests that it may have had a longer duration at this site.

Within the Paleocene, first occurrences of cosmopolitan DWAF can be used to refine the chronostratigraphic calibration of Hole 959D. The occurrence of the index species Reticulophragmoides jarvisi in Cores 159-959D-43R and 44R indicates a late Paleocene age. Additional taxa such as Trochammina ruthvenmurrayi and Glomospira diffundens are characteristic of the upper Paleocene in both Trinidad and the Carpathians. 
Table 1 (continued).

\begin{tabular}{|c|c|c|c|c|c|c|c|c|c|c|c|c|c|c|c|c|c|c|c|c|c|c|c|c|c|c|c|}
\hline $\begin{array}{l}\text { Core, section, } \\
\text { interval }(\mathrm{cm})\end{array}$ & 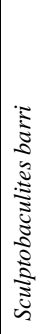 & 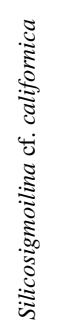 & 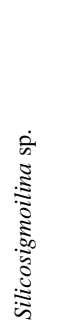 & 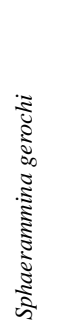 & 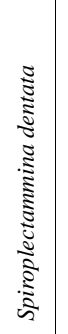 & 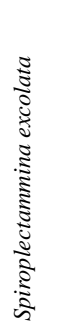 & 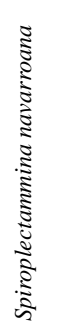 & 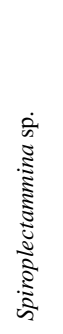 & 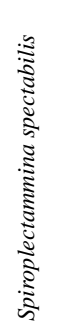 & 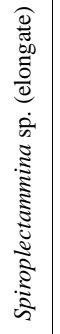 & 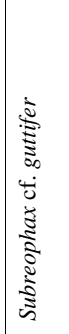 & 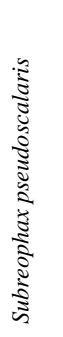 & 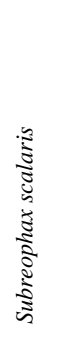 & 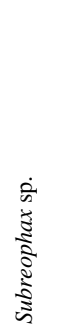 & 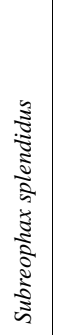 & 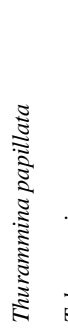 & 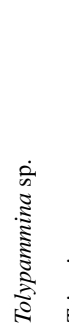 & 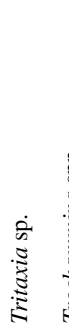 & 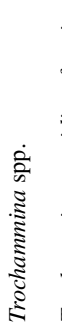 & 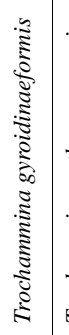 & 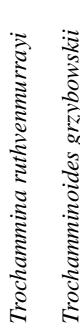 & 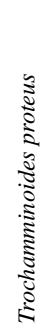 & 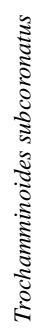 & 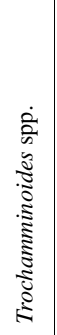 & 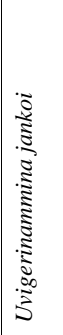 & 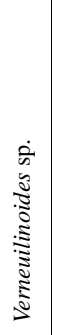 & 떵 \\
\hline 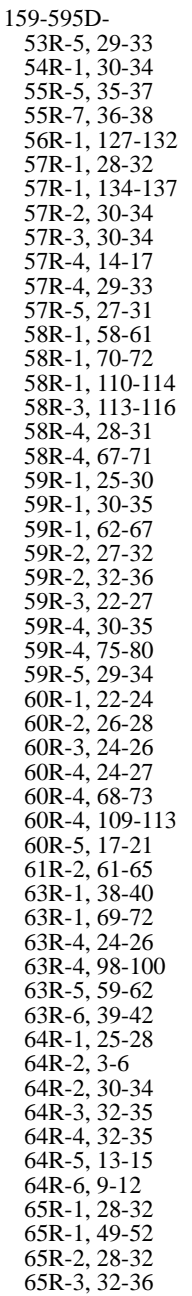 & : & 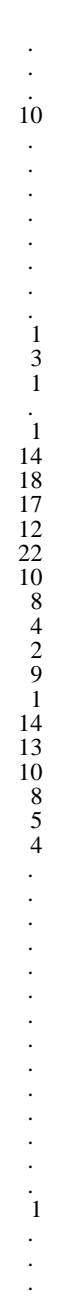 & 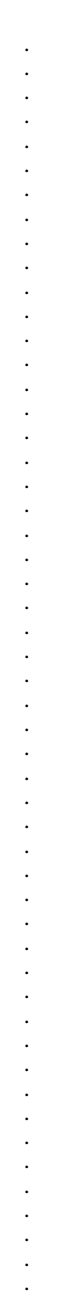 & $\begin{array}{l}: \\
: \\
: \\
: \\
: \\
: \\
: \\
: \\
: \\
: \\
: \\
: \\
: \\
: \\
: \\
: \\
: \\
: \\
: \\
: \\
: \\
: \\
: \\
: \\
: \\
: \\
: \\
: \\
: \\
: \\
: \\
:\end{array}$ & : & $\begin{array}{l}: \\
: \\
: \\
: \\
: \\
: \\
: \\
: \\
: \\
: \\
: \\
: \\
: \\
: \\
: \\
: \\
: \\
: \\
: \\
: \\
: \\
: \\
: \\
: \\
: \\
.\end{array}$ & 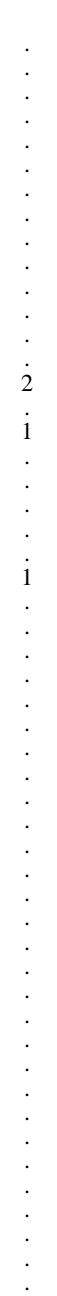 & 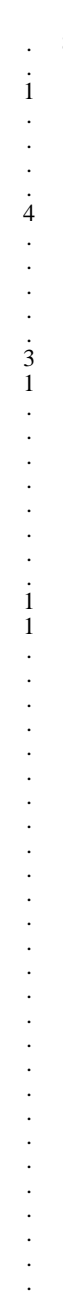 & 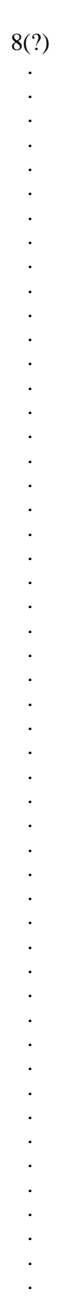 & 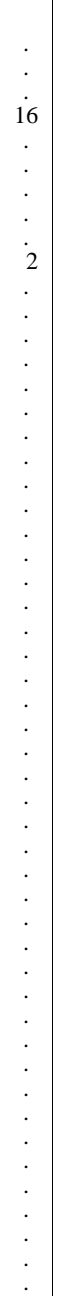 & 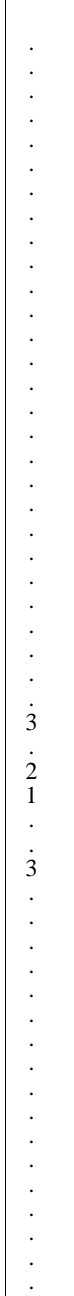 & $\begin{array}{l}: \\
: \\
\vdots \\
\vdots\end{array}$ & $\begin{array}{l}1 \\
5 \\
1 \\
3\end{array}$ & 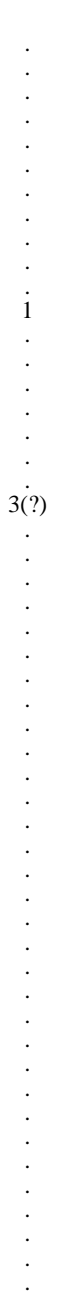 & 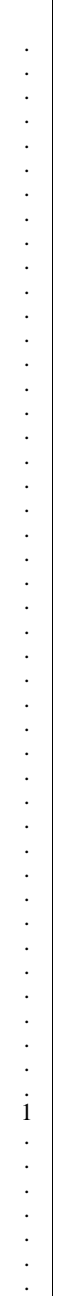 & i. & $\begin{array}{l}\dot{ } \\
\dot{ } \\
\dot{ }\end{array}$ & 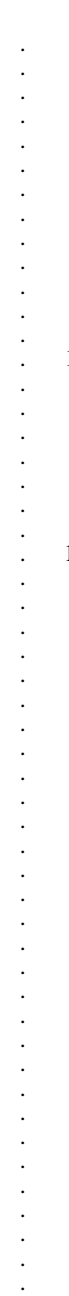 & $\begin{array}{c}9 \\
\\
\end{array}$ & 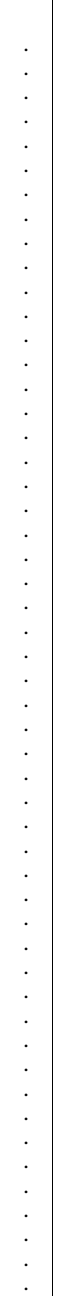 & . & : & $\begin{array}{l}\dot{A} \\
\vdots\end{array}$ & 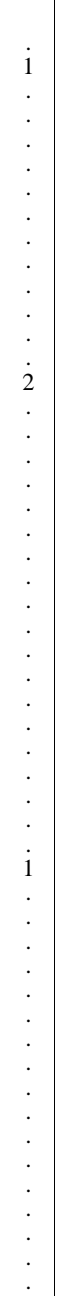 & 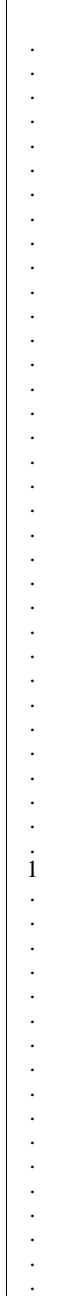 & 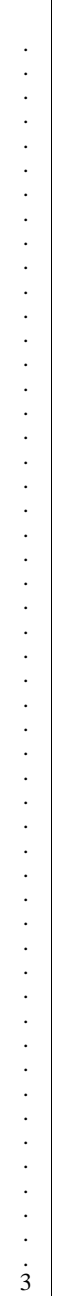 & 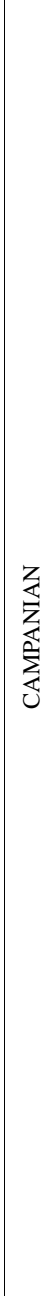 \\
\hline
\end{tabular}

Using all these DWAF occurrences and zones provides further evidence of the utility of these organisms for stratigraphic correlation on an ocean-wide scale.

\section{ACKNOWLEDGMENTS}

We thank Thomas Pletsch for sharing his first-hand shipboard experience and information with us, for organizing the sample processing in the "alternative clay mineralogy lab" at Kiel, and for numerous discussions over the last two years on the stratigraphy and paleoecology of Site 959. Ivan and Sandrine de Klasz made comparative material from the Danian of Senegal available to WK. MAK thanks Richard Norris (WHOI) for kindly providing access to his corecatcher samples from Hole 959D. We also thank Christoph Hemleben and Eduardo A.M. Koutsoukos for their constructive reviews of an initial version of the manuscript. Specimens were photographed using a Camscan 44 SEM at Kiel and a Zeiss 940 SEM at UCL; U. Schuldt (Kiel) and J. Davey (UCL) are thanked for photographic work, and Bruno Jeanguyot (Nice) is thanked for technical assistance. This study was supported by the Deutsche Forschungsgemeinschaft grant $\mathrm{Ku}$ 649/2 ("Atlantic Gateways") and grants from the British Council and DAAD (BC-Alliance Programme grant to MAK and MM; BC-DAAD Academic Exchange Programme grant no. 797 to MAK and WK). This is contribution no. 55 of the Deep Water Agglutinated Foraminiferal Project, and no. 132 of the UMR-CNRS "Geosciences Azur," Nice.

\section{REFERENCES}

Bubik, M., 1995. Cretaceous to Paleogene agglutinated foraminifera of the Bile Karpaty Unit (West Carpathians, Czech Republic). In Kaminski, 
M.A., Geroch, S., and Gasinski, M.A. (Ed.), Proceedings of the Fourth International Workshop on Agglutinated Foraminifera. Grzybowski Found. Spec. Publ., 3:71-116.

Butt, A., 1981. Depositional environments of the Upper Cretaceous rocks in the northern part of the Eastern Alps. Spec. Publ. Cushman Found. Foraminiferal Res., 20:1-121.

Caron, M., 1985. Cretaceous planktic foraminifera. In Bolli, H.M., Saunders, J.B., and Perch-Nielsen, K. (Eds), Plankton Stratigraphy: Cambridge (Cambridge Univ. Press), 17-86.

Coccioni, R., and Galeotti, S., 1994. K-T boundary extinction: geologically instantaneous or gradual event? Evidence from deep-sea benthic foraminifera. Geology, 22:779-782.

Cushman, J.A., and Renz, H.H., 1946. The foraminferal fauna of the Lizard Springs Formation of Trinidad, British West Indies. Spec. Publ. Cushman Lab. Foraminiferal Res., 18:1-48.

Geroch, S., and Nowak, W., 1984. Proposal of zonation for the late Tithonian-Eocene, based upon the arenaceous foraminifera from the outer Carpathians, Poland. In Oertli, H.J. (Ed.), BENTHOS '83: 2nd Int. Symp. Benthic Foraminifera. Bull. Cent. Rech. Explor.-Prod. Elf-Aquitaine, 6:225-239.

Gradstein, F.M., and Kaminski, M.A., 1989. Taxonomy and biostratigraphy of new and emended species of Cenozoic deep-water agglutinated foraminifera from the Labrador and North Seas. Micropaleontology, 35:7292.

Hemleben, C., and Troester, J., 1984. Campanian-Maestrichtian deep-water foraminifers from Hole 534A, Deep Sea Drilling Project. In Biju-Duval, B., Moore, J.C., et al., Init. Repts. DSDP, 78A: Washington (U.S. Govt. Printing Office), 509-532.

Herm, D., 1962. Stratigraphische und mikropaläontologische Untersuchungen der Oberkreide im Lattengebirge und Nierental (Gosaubecken von Reichenhall und Salzburg). Bayerische Akad. Wiss. Abh., Math.-Naturw. Kl., 104:1-119.

Kaminski, M.A., 1984. Shape Variation in Spiroplectammina spectabilis (Grzybowski). Acta Palaeontol. Polonica, 29:29-49.

1988. Cenozoic deep-water agglutinated foraminifera in the North Atlantic [Ph.D. thesis]. Woods Hole Oceanogr. Inst./Mass. Inst. Technol., Joint Program in Oceanography.

Kaminski, M.A., and Geroch, S., 1993. A revision of foraminiferal species in the Grzybowski Collection. In Kaminski, M.A., Geroch, S., and Kaminski, D.G. (Eds.), The Origins of Applied Micropalaeontology: The School of Józef Grzybowski. Grzybowski Found. Spec. Publ., 1:239-323.

Kaminski, M.A., Gradstein, F.M., Berggren, W.A., Geroch, S., and Beckmann, J.P., 1988. Flysch-type agglutinated foraminiferal assemblages from Trinidad: taxonomy, stratigraphy and paleobathymetry. Abh.Geol. Bundesanst., 41:155-227.

Kaminski, M.A., Kuhnt, W., and Radley, J., 1996. Palaeocene-Eocene deep water agglutinated foraminifera from the Numidian Flysch (Rif, Northern Morocco): their significance for the palaeoceanography of the Gibraltar gateway. J. Micropaleontol., 15:1-19.

Koch, W., 1977. Biostratigraphie in der Oberkreide und Taxonomie von Foraminiferen. Geol. Jahrb., Reihe A, 38:11-123.

Koutsoukos, E.A.M., 1992. Late Aptian to Maastrichtian foraminiferal biogeography and paleoceanography of the Sergipe Basin, Brazil. Palaeogeogr., Palaeoclimatol., Palaeoecol., 92:295-324.

Koutsoukos, E.A.M., and Bengtson, P., 1993. Towards an integrated biostratigraphy of the upper Aptian-Maastrichtian of the Sergipe Basin, Brazil. Doc. Lab. Geol. Lyon, 125:241-262.

Koutsoukos, E.A.M., Destro, N., Azambuja Filho, N.C., and Spadini, A.R., 1993. Upper Aptian-lower Coniacian carbonate sequences in the Sergipe Basin, northeastern Brazil. In Simo, T., Scott, R.W., and Masse, J.-P. (Eds.), Cretaceous Carbonate Platforms. AAPG Mem., 56:127-144.

Koutsoukos, E.A.M., and Hart, M.B., 1990. Cretaceous foraminiferal morphogroup distribution patterns, palaeocommunities and trophic structures: a case study from the Sergipe Basin, Brazil. Trans. R. Soc. Edinburgh: Earth Sci., 81:221-246.

Kuhnt, W., 1990. Agglutinated foraminifera of western Mediterranean Upper Cretaceous pelagic limestones (Umbrian Apennines, Italy, and betic Cordillera, Southern Spain). Micropaleontology, 36:297-330.

- 1992. An early Campanian paleoceanographic event in the North Atlantic and Western Tethys? Fourth Int. Conf. Paleoceanogr., ICP IV. Geomar Rep. 15/Rep., Geol. Palaeontol. Inst. Univ. Kiel, 57:171.

Kuhnt, W., and Collins, E.S., 1996. Cretaceous to Paleogene benthic foraminifers from the Iberia Abyssal Plain. In Whitmarsh, R.B., Sawyer,
D.S., Klaus, A., and Masson, D.G. (Eds.), Proc. ODP, Sci. Results, 149: College Station, TX (Ocean Drilling Program), 203-216.

Kuhnt, W., Geroch, S., Kaminski, M.A., Moullade, M., and Neagu, T., 1992. Upper Cretaceous abyssal claystones in the North Atlantic and Western Tethys: current status of biostratigraphical correlation using agglutinated foraminifers and palaeoceanographic events. Cretaceous Res., 13:467478.

Kuhnt, W., and Kaminski, M.A., 1989. Upper Cretaceous deep-water agglutinated benthic foraminiferal assemblages from the Western Mediterranean and adjacent areas. In Wiedmann, J. (Ed.), Cretaceous of the Western Tethys: Stuttgart (Schweizerbart), 91-120.

1990. Paleoecology of Late Cretaceous to Paleocene deep-water agglutinated foraminifera from the North Atlantic and western Tethys. In Hemleben, C., Kaminski, M.A., Kuhnt, W., and Scott, D.B. (Eds.), Paleoecology, Biostratigraphy, Paleoceanography and Taxonomy of Agglutinated Foraminifera: Dordrecht (Kluwer), 433-505.

1993. Changes in the community structure of deep-water agglutinated foraminifers across the $\mathrm{K} / \mathrm{T}$ boundary in the Basque Basin (Northern Spain). Rev. Esp. Micropaleontol., 25:57-92.

1996. The response of benthic foraminifera to the K/T boundary event: a review. In Géologie de l'Afrique et de l'Atlantique Sud: Actes Colloques Angers 1994. Elf Aquitaine Édition (Memoire 16: 433-442).

Kuhnt, W., Kaminski, M.A., and Moullade, M., 1989. Late Cretaceous deepwater agglutinated foraminiferal assemblages from the North Atlantic and its marginal seas. Geol. Rundsch., 78:1121-1140.

Kuhnt, W., and Moullade, M., 1991. Quantitative analysis of upper Cretaceous abyssal agglutinated foraminiferal distribution in the North Atlantic-paleoceanographic implications. Rev. Micropaleontol., 34:313-349.

Kuhnt, W., Moullade, M., and Kaminski, M.A., 1996. Ecological structuring and evolution of deep sea agglutinated foraminifera: a review. Rev. Micropaleont., 34:271-281.

Moullade, M., Kuhnt, W., and Thurow, J., 1988. Agglutinated benthic foraminifers from Upper Cretaceous variegated clays of the North Atlantic Ocean (DSDP Leg 93 and ODP Leg 103). In Boillot, G., Winterer, E.L., et al., Proc. ODP, Sci. Results, 103: College Station, TX (Ocean Drilling Program), 349-377.

Neagu, T., 1968. Biostratigraphy of Upper Cretaceous deposits in the southern Eastern Carpathians near Brasov. Micropaleontology, 14:225-241.

Volat, J.-L, Hugo, B., and Bignoumba-Ilogue, J., 1996. Foraminifères arénacés du Crétacé supérieur du Gabon-Arenaceous foraminifera from the late Cretaceous of Gabon. Bull. Centres Rech. Explor-Prod. Elf Aquitaine, 20:229-275.

Wightman, W.G., and Kuhnt, W., 1992. Biostratigraphy and paleoecology of Late Cretaceous abyssal agglutinated foraminifers from the western Pacific Ocean (Deep Sea Drilling Project Holes 196A and 198A and Ocean Drilling Program Holes 800A and 801A). In Larson, R.L., Lancelot, Y., et al., Proc. ODP, Sci. Results, 129: College Station, TX (Ocean Drilling Program), 247-264.

\section{SPECIES LIST}

Most of the species mentioned are described and illustrated in Geroch and Nowak (1984), Moullade et al. (1988), Kaminski et al. (1988), Kuhnt (1990), Kuhnt and Kaminski (1990, 1993), Kaminski and Geroch (1993), and Kaminski et al. (1996).

Ammobaculites sp.

Ammodiscus cretaceus (Reuss)

Ammodiscus ex gr. pennyi (Cushman and Jarvis)

Ammodiscus glabratus (Cushman and Jarvis)

Ammodiscus peruvianus (Berry)

Ammodiscus tenuissimus Grzybowski

Ammolagena clavata (Jones and Parker)

Ammoscalaria sp.

Ammosphaeroidina sp., mostly Ammosphaeroidina pseudopauciloculata (Mjatliuk)

Aschemocella spp. (incl. fragments)

Bathysiphon spp.

Budashevaella multicamerata (Veloshinova)

Bulbobaculites ex gr. problematicus (Neagu)

Bulbobaculites sp.

Buzasina sp.

Caudammina gigantea (Geroch)

Caudammina ovuloides (Grzybowski)

Caudammina ovula (Grzybowski) 
Clavulinoides spp.

Conotrochammina whangaia Finlay

Cribrostomoides sp.

Dorothia ex gr. filiformis (Berthelin)

Dorothia sp.

Evolutinella (?) sp., similar to Evolutinella ewongueensis Volat, Hugo and Bignoumba-Ilogue, 1996

Gaudryina sp.

Glomospira charoides (Jones and Parker)

Glomospira diffundens (Cushman and Renz)

Glomospira glomerata (Grzybowski)

Glomospira gordialis (Jones and Parker)

Glomospira irregularis (Grzybowski)

Glomospira serpens (Grzybowski)

Glomospirella grzybowskii (Jurkiewicz)

Haplophragmoides ex gr. excavatus (Cushman and Waters)

Haplophragmoides cf. walteri (Grzybowski) of Kuhnt and Kaminski (1990)

Haplophragmoides horridus (Grzybowski)

Haplophragmoides porrectus (Maslakova)

Haplophragmoides sp ?kirki Wickenden

Haplophragmoides suborbicularis (Grzybowski)

Haplophragmoides stomatus (Grzybowski)

Haplophragmoides walteri (Grzybowski)

Haplophragmoides sp.

Hippocrepina sp.

Hormosina trinitatensis (Cushman and Renz)

Hormosina velascoensis (Cushman)

Hyperammina dilatata (Grzybowski)

Hyperammina sp. (incl. fragments)

Insculptarenula sp.

Kalamopsis grzybowskii (Dylazanka)

Karrerulina conversa (Grzybowski)

Karrerulina spp.

Lagenammina sp.

Lituotuba lituiformis (Brady)

Nothia excelsa (Grzybowski)

Paratrochamminoides irregularis (White)

Paratrochamminoides mitratus (Grzybowski)

Paratrochamminoides olszewskii (Grzybowski)

Paratrochamminoides spp.

Popovia beckmanni (Kaminski and Geroch)

Psammosphaera fusca Schultze

Pseudobolivina lagenaria Krashenninikov

Pseudobolivina spp.

Recurvoidella lamella (Grzybowski)

Recurvoides deflexiformis (Noth) sensu Geroch

Recurvoides $\mathrm{sp}$.

Reophax duplex Grzybowski

Reophax pilulifer Brady
Reophax sp. 2

Reophax subfusiformis Hoeglund

Reophax spp.

Reticulophragmoides jarvisi (Thalmann)

Rhabdammina sp.

Rhizammina (large)

Rhizammina spp.

Rzehakina epigona (Rzehak)

Rzehakina epigona lata (Cushman and Jarvis)

Rzehakina ex gr. epigona (Rzehak)

Rzehakina fissistomata (Grzybowski)

Rzehakina inclusa (Grzybowski)

Rzehakina minima (Cushman and Renz)

Rzehakina sp. (narrow)

Saccammina grzybowskii (Schubert)

Saccammina placenta (Grzybowski)

Saccorhiza ramosa Brady

Sculptobaculites barri Beckmann

Silicosigmoilina cf. californica Cushman and Church

Sphaerammina gerochi Hanzlikova

Spiroplectammina dentata (Alth)

Spiroplectammina excolata (Cushman)

Spiroplectammina navarroana (Cushman)

Spiroplectammina sp.

Spiroplectammina spectabilis (Grzybowski)

Spiroplectammina sp. (elongate)

Subreophax cf. guttifer (Brady)

Subreophax pseudoscalaris (Samuel)

Subreophax scalaris (Grzybowski)

Subreophax sp.

Subreophax splendidus (Grzybowski)

Textularia sp.

Thurammina papillata Brady

Trochammina ruthvenmurrayi Cushman and Renz

Trochammina spp.

Trochamminoides grzybowskii Kaminski and Geroch

Trochamminoides proteus (Karrer)

Trochamminoides subcoronatus (Grzybowski)

Trochamminoides spp.

Uvigerinammina jankoi Majzon

Verneuilinoides sp.

Date of initial receipt: 23 September 1996

Date of acceptance: 4 June 1997

Ms 159SR-039 


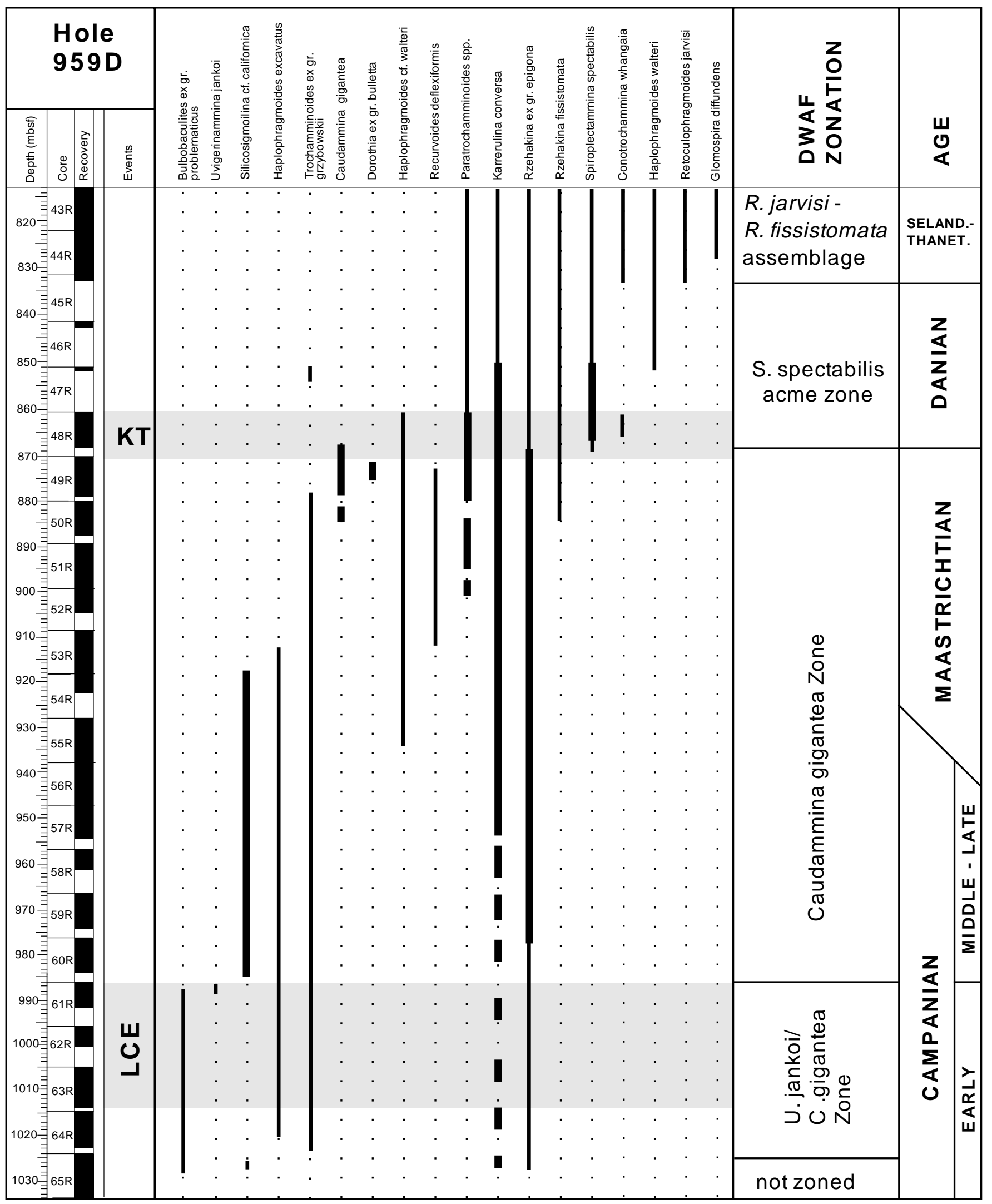

Figure 2. Stratigraphic ranges of marker species of agglutinated foraminifers within Hole 959D, Cores 159-959D-43R through 65R. Paleoceanographic events: $\mathrm{KT}=$ Cretaceous/Tertiary Boundary Event; LCE $=$ Lower Campanian Event. 

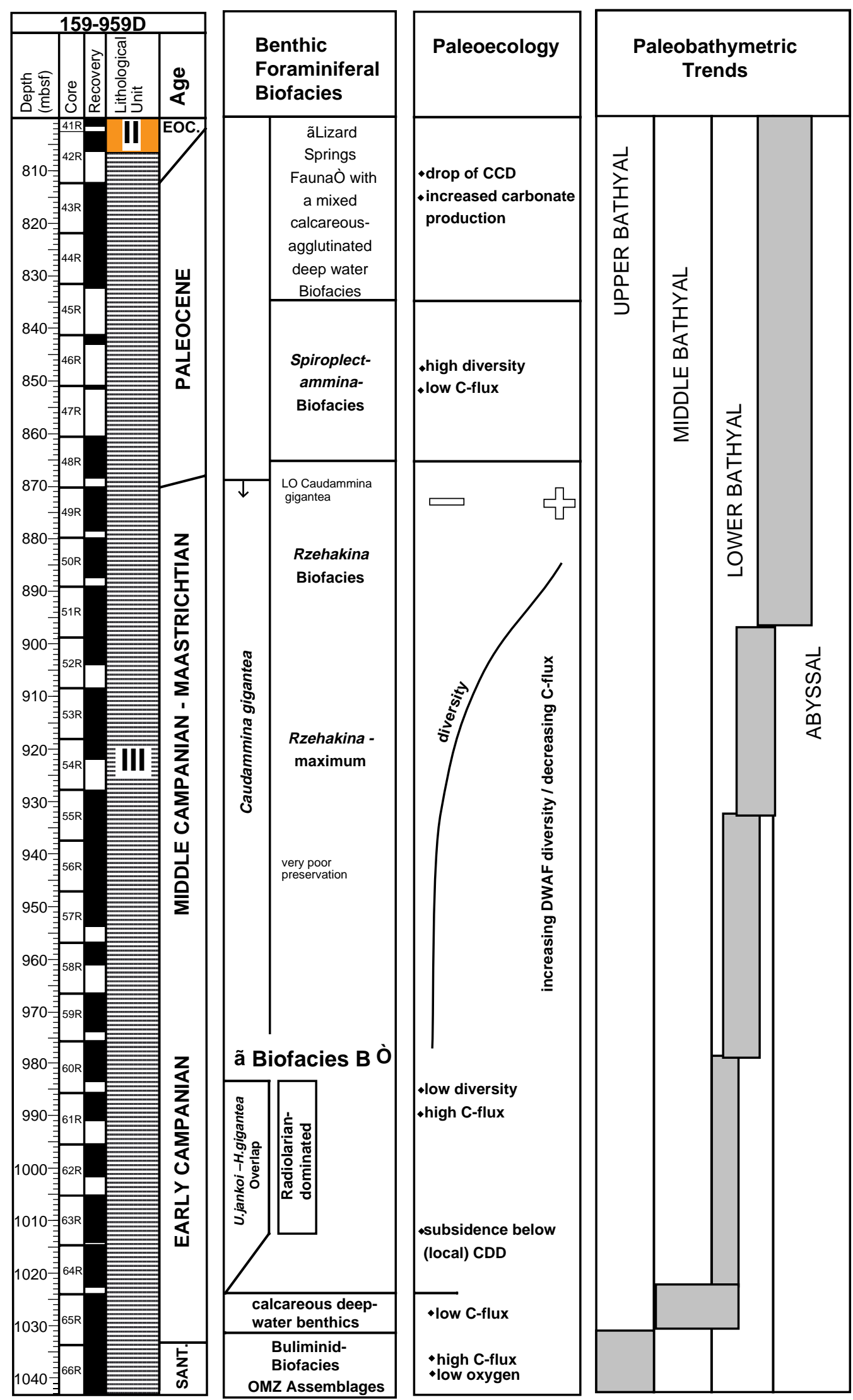

Figure 3. Benthic foraminifer biofacies and inferred paleoecologic-paleobathymetric trends in Hole 959D. 


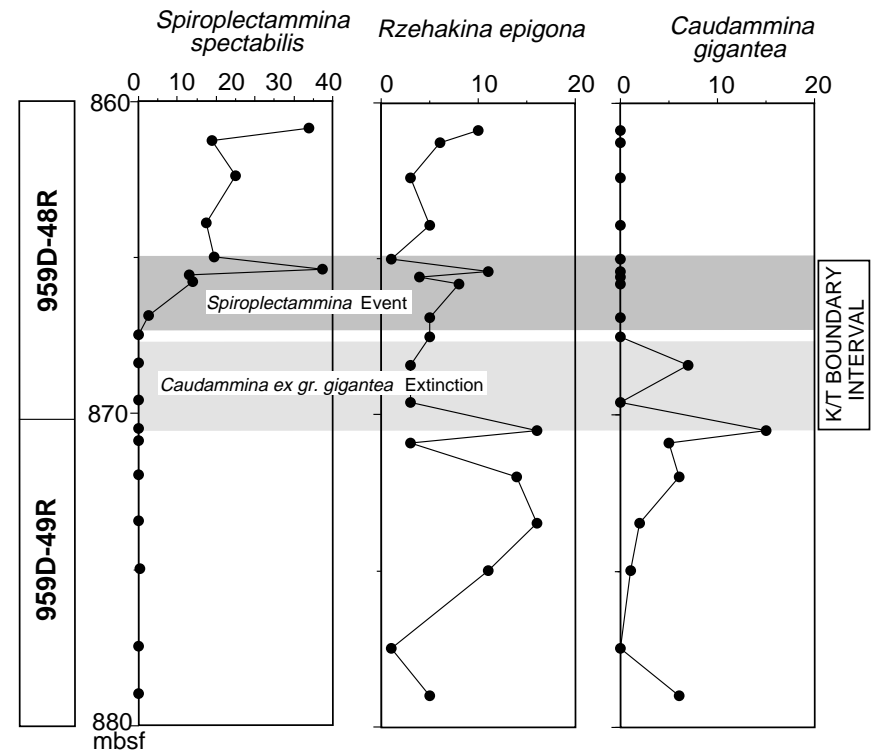

Figure 4. Quantitative changes of selected benthic foraminifer abundances across the K/T boundary interval in Hole 959D. 


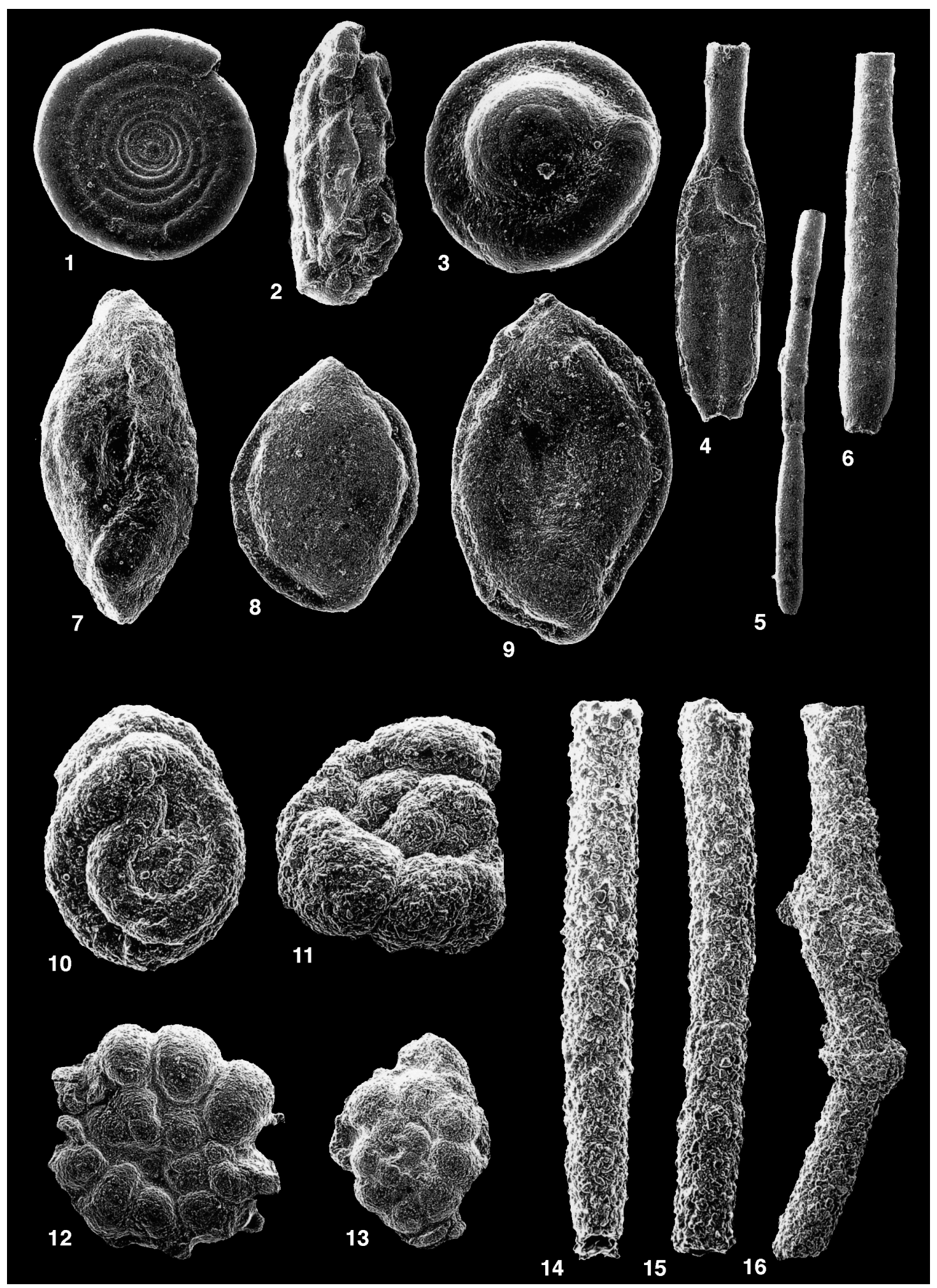

Plate 1. 1. Ammodiscus cretaceus, (35×), Sample 159-959D-49R-1, 28-31 cm. 2. Glomospira serpens, (65×), Sample 159-959D-49R-1, 28-31 cm. 3. Glomospira charoides, (130×), Sample 159-959D-49R-1, 28-31 cm. 4. Kalamopsis grzybowskii, (85×), Sample 159-959D-49R-1, 28-31 cm. 5. Kalamopsis grzybowskii, (35×), Sample 159-959D-48R-4, 48-50 cm. 6. Kalamopsis grzybowskii, (55×), Sample 159-959D-48R-4, 48-50 cm. 7. (85×), Rzehakina inclusa, Sample 159-959D-65R-1, 49-52 cm. 8. Rzehakina epigona, (85×), Sample 159-959D-49R-1, 28-31 cm. 9. Rzehakina epigona, (90×), Sample 159-959D-49R1, 28-31 cm. 10. Glomospira irregularis, (105×), Sample 159-959D-49R-1, 110-114 cm. 11. Paratrochamminoides sp., (70×), Sample 159-959D-49R-1, 110$114 \mathrm{~cm}$. 12. Paratrochamminoides sp., (30×), Sample 159-959D-50R-4, 68-71 cm. 13. Paratrochamminoides acervulatus, (30X), Sample 159-959D-50R-4, 68-71 cm. 14.-16. Rhabdammina cylindrica, (14: 40×, 15: 30×, 16: 25×), Sample 159-959D-49R-2, 27-30 cm. 


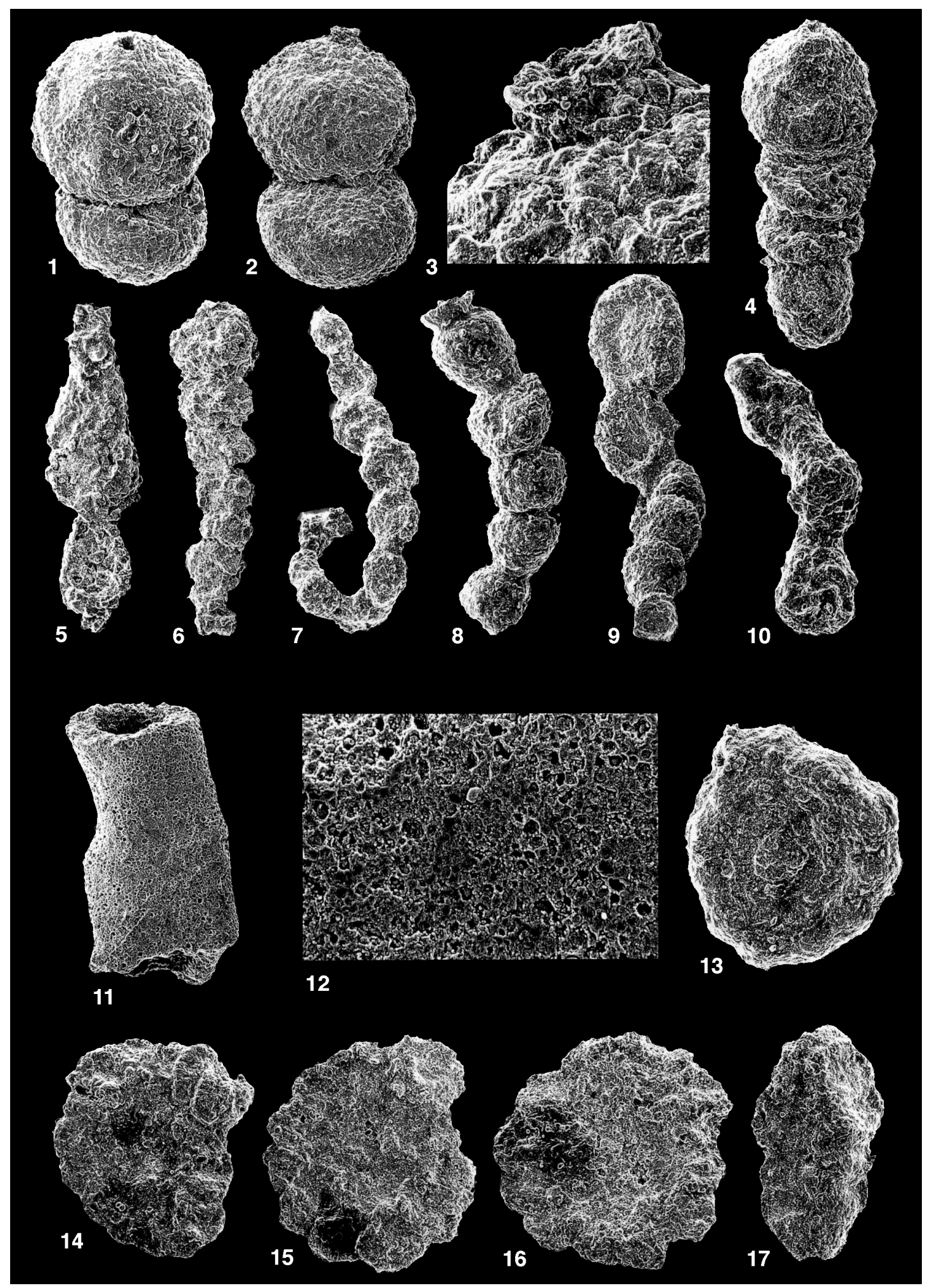

Plate 2. 1. Reophax duplex, (50×), Sample 159-959D-50R-3, 28-31 cm. 2. Reophax duplex, (40×), Sample 159-959D-50R-3, 28-31 cm. 3. Detail of Fig. 2, aperture protruding on a short neck, (205×). 4. Reophax sp., (100×), Sample 159-959D-49R-1, 28-31 cm. 5. Reophax sp., (60×), Sample 159-959D-50R-2, 2629 cm. 6. Subreophax sp., (45×), Sample 159-959D-50R-2, 26-29 cm. 7. Subreophax scalaris, (75×),Sample 159-959D-50R-2, 26-29 cm. 8. Subreophax scalaris, (60×), Sample 159-959D-49R-1, 28-31 cm. 9. Subreophax sp., (65×), Sample 159-959D-49R-1, 28-31 cm. 10. Subreophax ex gr. guttifer, (130×), Sample 159-959D-61R-2, 61-65 cm. 11. Nothia ex gr. excelsa, (60×), Sample 159-959D-65R-4, 95-98 cm. 12. Detail of Fig. 1 showing dissolution of agglutinated carbonate grains, (245×). 13. Trochamminoides sp., (90×), Sample 159-959D-50R-2, 26-29 cm. 14.-17. Evolutinella sp., Sample 159-959D-65R-2, 28-32 cm $(14,16: 85 \times ; 15,17: 80 \times)$. 

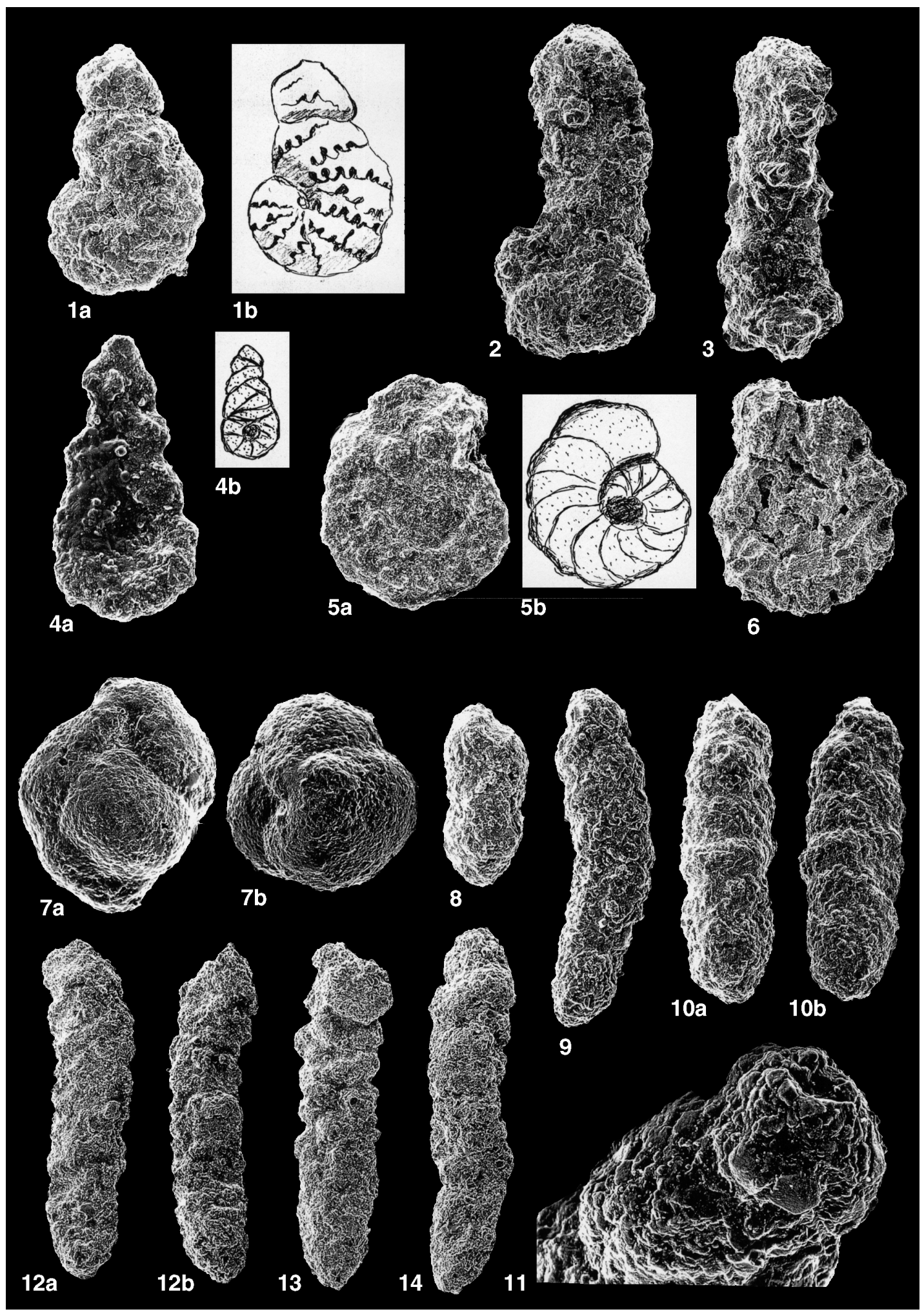

Plate 3. 1a, b. Reticulophragmium sp. (early form), (60×), Sample 159-959D-50R-3, $28-31 \mathrm{~cm}$. 2. Bulbobaculites problematicus, (115×), Sample 159-959D65R-2, 28-32 cm. 3. Bulbobaculites problematicus, (100×), Sample 159-959D-65R-2, 28-32 cm. 4a, b. Ammoscalaria sp., (a: 150×; b: 65×), Sample 159959D-50R-2, 26-29 cm. 5a, b. Ammoscalaria sp., (75×), Sample 159-959D-50R-2, $26-29$ cm. 6. Ammobaculites sp., (50×), Sample 159-959D-50R-3, 28-31 cm. 7a, b. Uvigerinammina jankoi, (100×), Sample 159-959D-61R-2, 61-65 cm. 8. Karrerulina conversa (juvenile form, 90×), Sample 159-959D-49R-1, 28$31 \mathrm{~cm}$. 9. Karrerulina conversa, (75×), Sample 159-959D-49R-1, 28-31 cm. 10a, b. Karrerulina conversa, (75×), Sample 159-959D-49R-1, 28-31 cm. 11. Detail of Fig. 10 with terminal aperture, (240×). 12a, b. Dorothia ex gr. filiformis, (70×), Sample 159-959D-65R-2, 28-32 cm. 13. Dorothia ex gr. filiformis, (70×), Sample 159-959D-65R-2, 28-32 cm. 14. Dorothia ex gr. filiformis, (70×), Sample 159-959D-65R-4, 95-98 cm. 


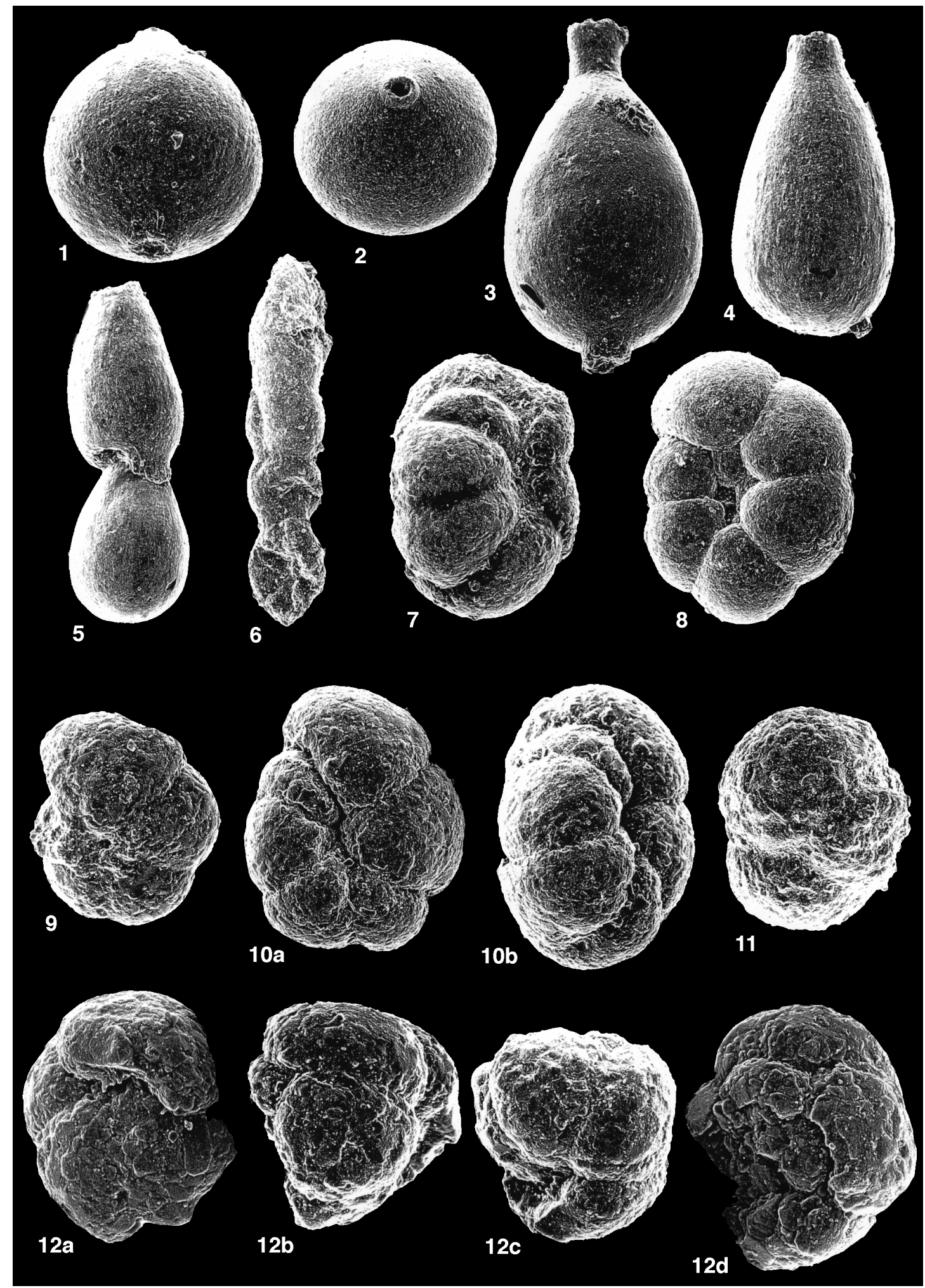

Plate 4. 1. Caudammina ovula, (115×), Sample 159-959D-49R-1, 28-31 cm. 2. Caudammina ovula, (115×), Sample 159-959D-49R-1, 28-31 cm. 3. Caudammina ovuloides, (75×), Sample 159-959D-49R-1, 28-31 cm. 4. Caudammina ovuloides, (75×), Sample 159-959D-49R-1, 110-114 cm. 5. Caudammina ovuloides, (75×), Sample 159-959D-49R-1, 110-114 cm. 6. Hormosina velascoensis, (90×), Sample 159-959D-50R-3, 28-31 cm. 7. Haplophragmoides sp., (100×), Sample 159-959D-49R-1, 28-31 cm. 8. Haplophragmoides ex gr. perexplicatus, (115×), Sample 159-959D-49R-4, 27-30 cm. 9. Haplophragmoides cf. decussatus, (150×), Sample 159-959D-49R-1, 28-31 cm. 10a, b. Haplophragmoides sp., (a: 125×; b: 135×), Sample 159-959D-49R-4, 27-30 cm. 11. Ammosphaeroidina pseudopauciloculata, (165×), Sample 159-959D-50R-2, 26-29 cm. 12a-d. Trochammina gyroidinaeformis (a,b: 220X; c: 200X: d: 245×).Sample 159-959D-49R-4, 27-30 cm. 


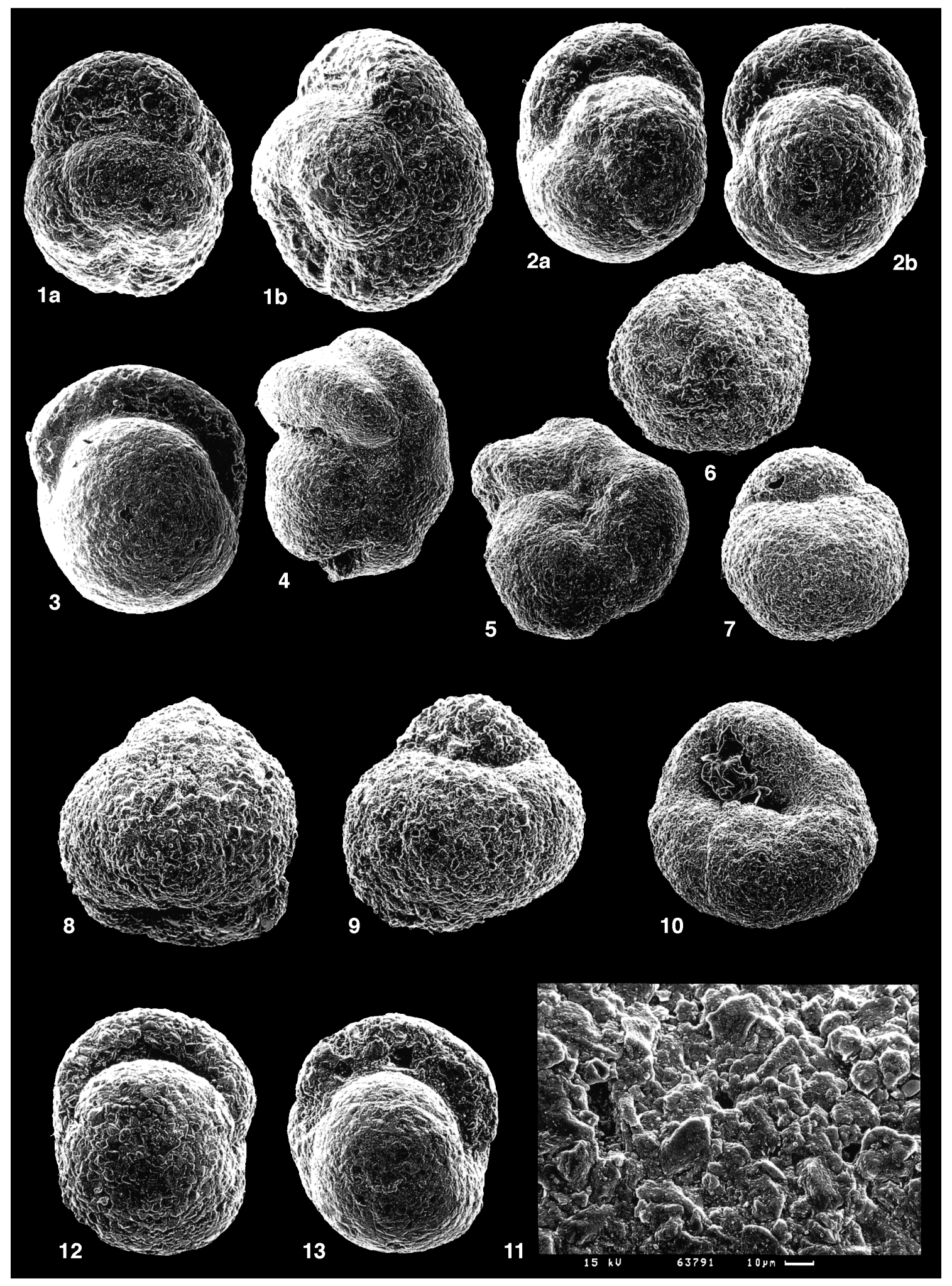

Plate 5. 1a, b. Recurvoides sp., (a: 70×; b: 75×), Sample 159-959D-49R-1, 110-114 cm. 2a, b. Recurvoides sp., (65×), Sample 159-959D-49R-1, 110-114 cm. 3. Recurvoides sp., (65×), Sample 159-959D-49R-1, 28-31 cm. 4. Recurvoides sp., (45×), Sample 159-959D-49R-1, 110-114 cm. 5. Recurvoides sp., (45×), Sample 159-959D-49R-1, 28-31 cm. 6. Conotrochammina cf. whangaia (dorsal view), (50×), Sample 159-959D-50R-3, 28-31 cm. 7. Conotrochammina cf. whangaia (ventral view), (50×), Sample 159-959D-50R-3, 28-31 cm. 8. Conotrochammina cf. whangaia (side view), (65×), Sample 159-959D-49R-4, 27-30 cm. 9. Conotrochammina cf. whangaia (ventral view), (70×), Sample 159-959D-49R-4, 27-30 cm. 10. Conotrochammina cf. whangaia (ventral view), (45×), Sample 159-959D-49R-4, 27-30 cm. 11. Detail of Fig. 10: perforate wall structure, (465×). 12. Cribrostomoides sp., (55×), Sample 159-959D-49R-3, 27-30 cm. 13. Cribrostomoides p., (80×), Sample 159-959D-49R-3, 27-30 cm. 


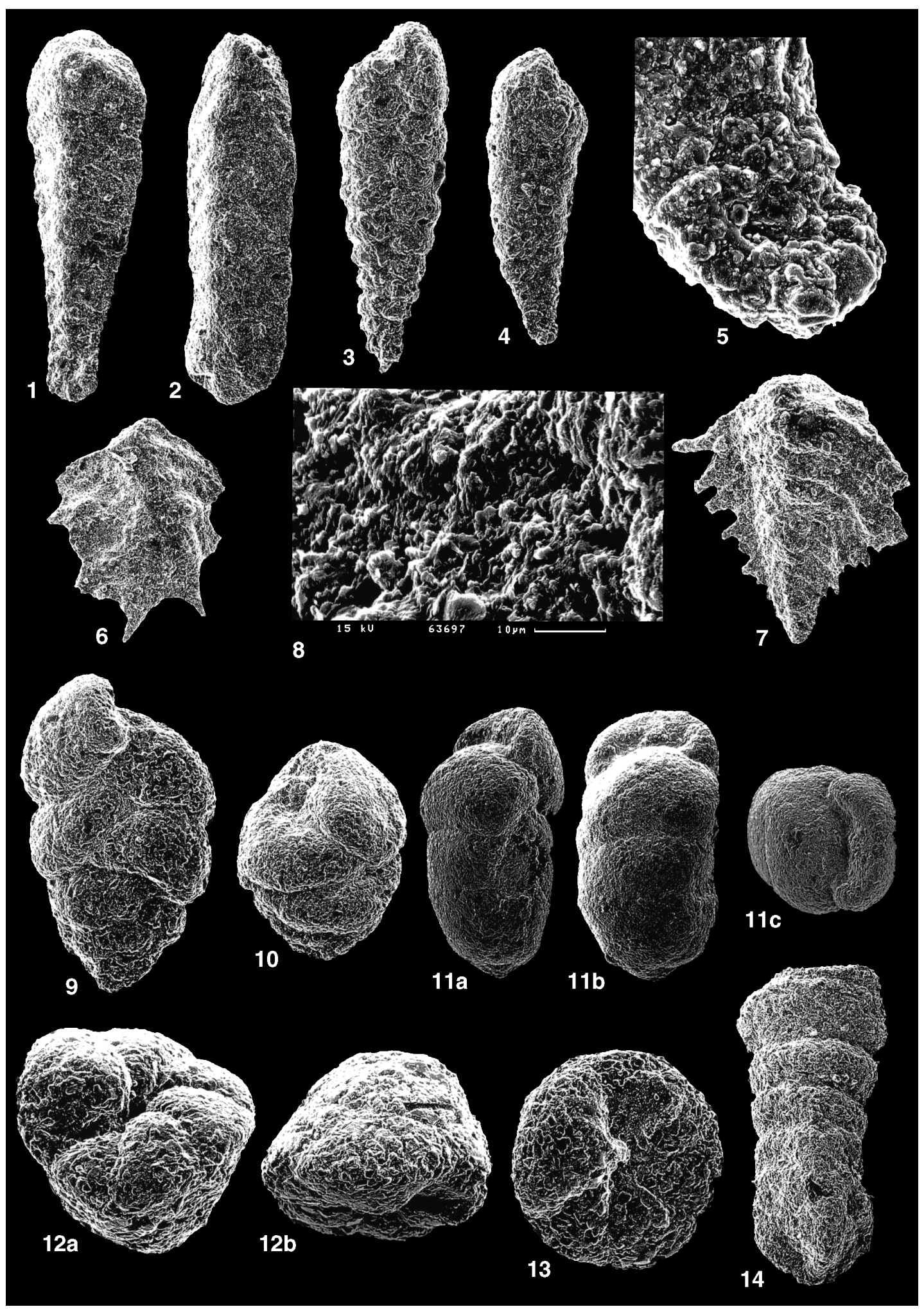

Plate 6. 1. Spiroplectammina spectabilis (microsphere), (110×), Sample 159-959D-48R-4, 48-50 cm. 2. Spiroplectammina spectabilis (megalosphere), (95×), Sample 159-959D-48R-4, 48-50 cm. 3. Spiroplectammina navarroana (microsphere), (80×), Sample 159-959D-49R-1, 28-31 cm. 4. Spiro-plectammina navarroana (megalosphere), (80×), Sample 159-959D-49R-1, 28-31 cm. 5. Detail of 4 with spiral initial portion, (440X), Sample 159-959D-49R-1, 28-31 cm. 6. Spiroplectammina ex gr. dentata (megalosphere), (70×), Sample 159-959D-50R-2, 26-29 cm. 7. Spiroplectammina ex gr. dentata (microsphere), (70×), Sample 159-959D-50R-2, 26-29 cm. 8. Detail of 7 showing microperforate wall, (1080×), Sample 159-959D-50R-2, 26-29 cm. 9. Remesella varians (?), (45×), Sample 159-959D-49R-4, 69-72 cm. 10. Remesella varians (?), (50×), Sample 159-959D-49R-4, 69-72 cm. 11a-c. Dorothia bulletta, (35×), Sample 159959D-50R-4, 68-71 cm. 12a-b. Trochammina ruthvenmurrayi, (90×), Sample 159-959D-49R-3, 27-30 cm. 13. Trochammina ruthvenmurrayi, (90×), Sample 159-959D-49R-3, 27-30 cm. 14. Clavulinoides sp., (40×), Sample 159-959D-49R-4, 69-72 cm. 


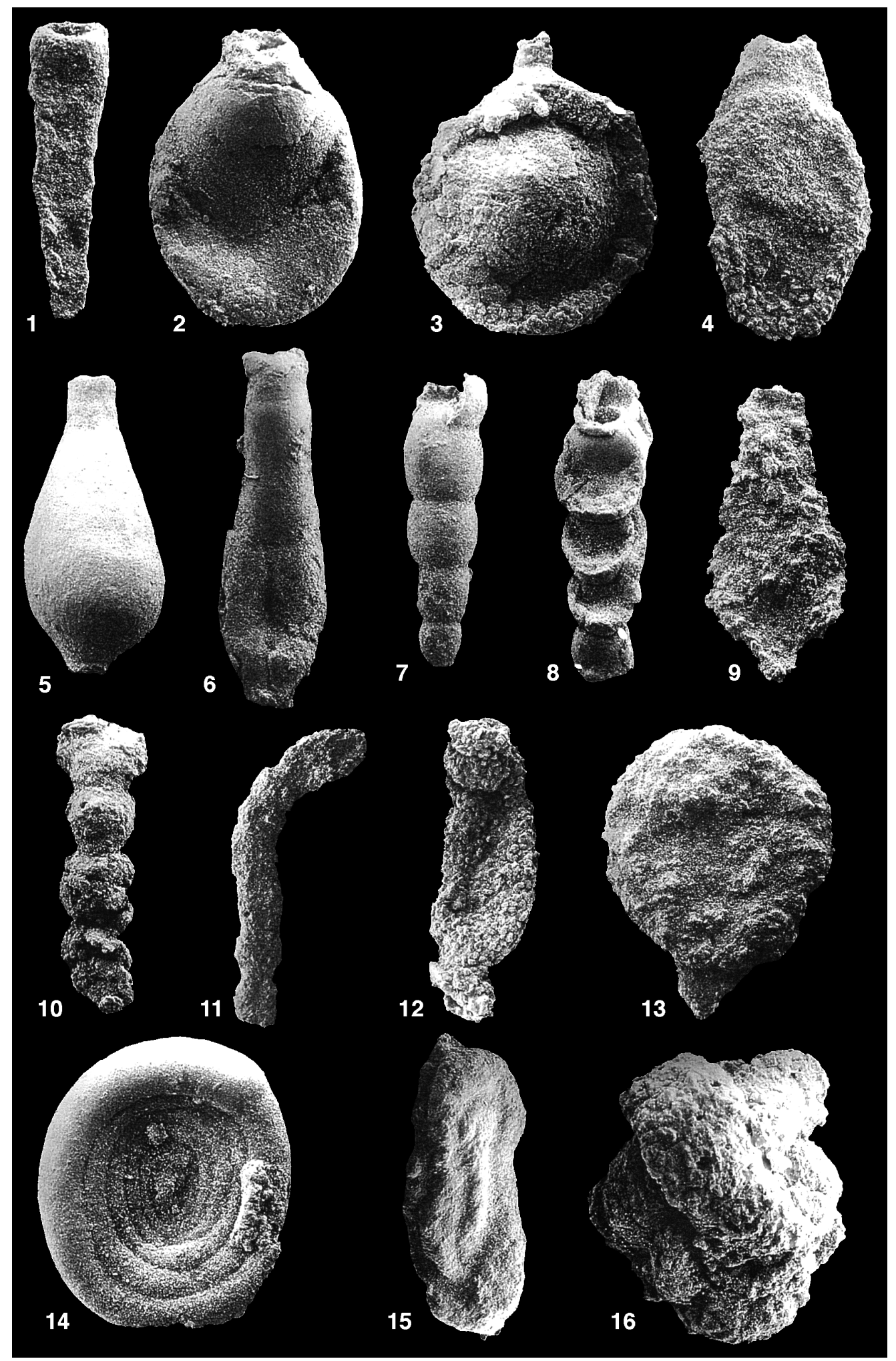

Plate 7. 1. Hippocrepina sp., (115×), Sample 159-959D-44R-6, 30-33 cm. 2. Hyperammina dilatata, (60×), Sample 159-959D-46R-1, 80-85 cm. 3. Saccammina grzybowskii, (165×), Sample 159-959D-48R, CC. 4. Aschemocella sp., (50×), Sample 159-959D-47R-1, 19-22 cm. 5. Caudammina ovuloides, (55×), Sample 159-959D-48R, CC. 6. Kalamopsis grzybowskii, (35×), Sample 159-959D-46R-1, 80-85 cm. 7. Reophax nodulosus, (35X), Sample 159-959D-45R-1, 43-48 cm. 8. Hormosina velascoensis, (20×), Sample 159-959D-45R, CC. 9. Lagenammina sp., (60×), Sample 159-959D-47R-1, 19-22 cm. 10. Subreophax scalaris, (70×), Sample 159-959D-46R-1, 80-85 cm. 11. Subreophax scalaris, (55×), Sample 159-959D-47R-1, 19-22 cm. 12. Subreophax splendidus, (65×), Sample 159-959D-48R, CC. 13. Aschemocella grandis, (50×), Sample 159-959D-47R-1, 19-22 cm. 14. Ammodiscus glabratus, (115×), Sample 159-959D48R, CC. 15. Glomospira serpens, (65×), Sample 159-959D-45R-1, 43-48 cm. 16. Glomospira irregularis, (140×), Sample 159-959D-48R, CC. 


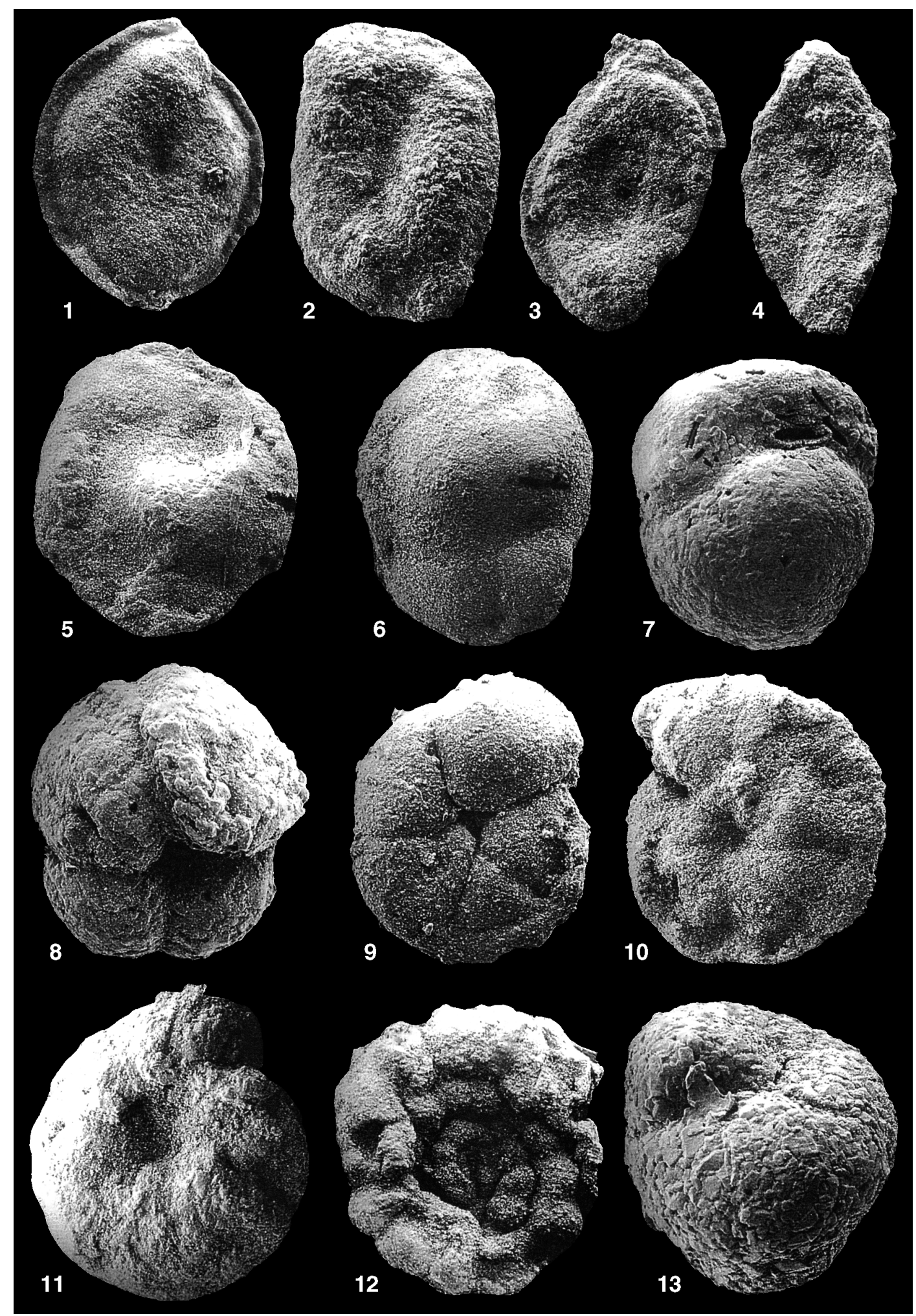

Plate 8. 1. Rzehakina epigona lata, a large specimen showing a well-developed keel, (35×), Sample 159-959D-45R-1, 43-48 cm. 2. Rzehakina epigona, (85×), Sample 159-959D-44R-6, 30-33 cm. 3. Rzehakina fissistomata, (60×), Sample 159-959D-44R-6, 30-33 cm. 4. Rzehakina minima, (85×), Sample 159-959D44R-6, 30-33 cm. 5. Buzasina sp., (60×), Sample 159-959D-45R, CC. 6. Buzasina sp., (65×), Sample 159-959D-45R, CC. 7. Cribrostomoides sp., (65×), Sample 159-959D-48R, CC. 8. Haplophragmoides kirki, (165×), Sample 159-959D-48R, CC. 9. Haplophragmoides cf. walteri of Kuhnt and Kaminski (1990), (165×), Sample 159-959D-48R, CC. 10. Reticulophragmoides jarvisi, an early form transitional to Haplophragmoides walteri, (75×), Sample 159-959D-46R-1, 80-85 cm. 11. Haplophragmoides sp., a distinctive form with a depressed umbilicus, (75×), Sample 159-959D-45R, CC. 12. Trochamminoides grzybowskii, (30×), Sample 159-959D-45R, CC. 13. Conotrochammina whangaia, (115×), Sample 159-959D-48R, CC. 